\title{
Group Identifications: African and Global Categories
}

\section{Defining African Ethnicities against a Global Background}

Discussions about group identifications in sub-Saharan Africa, and elsewhere in the world, are today dominated by a somewhat odd parallelism between different concepts, which are rarely understood as alternatives. This relates to the factors of ethnicity, religion, and the post-colonial nation-building projects: in the case of West Africa, for some regions, like Nigeria, the debate now favours religion almost exclusively as a divisive problem; in Ghana and Sierra Leone, regional and ethnic factors are broadly discussed; for Côte d'Ivoire, scholars seek explanations for what they regard as the failure of nationbuilding. The different factors, to which we can add family, kinship, and models of political organisation, are rarely brought into a larger panorama. Moreover, they are not really seen as different options for identification for an individual or for a group. ${ }^{1}$

The current chapter endeavours to give the reader a solid general idea about ethnic sentiment as a conceptual factor in sub-Saharan Africa and in its global dimensions. It addresses key problems in this context: the debate about the nature of ethnicity, with its slowly changing arguments over the last five decades; and the quest for a working definition of ethnic groups. Concerning the former, it is necessary to engage with a basic discussion of whether ethnic identification is a long-lasting 'traditional' fact or a construction under conditions of colonial rule: that is, would a member of a certain community have automatically been inclined to identify herself or himself as belonging to her or his ethnic group, or was she or he usually led or even manipulated to do so? The second problem is also quite intriguing. As we will see, scholars from different fields and experts on different geographical regions fill the flexible adjective 'ethnic' with quite distinct meanings. This situation makes it necessary to elaborate a useful definition for our context. Finally, the sub-chapters will refer to various elements of mobilisation, through alternative forms of identification. While religion is more evident as a factor, and will be directly

1 Diouf, Mamadou, 'Des Historiens et des Histoires, pour quoi faire? L'Histoire africaine entre l'état et les communautés', Canadian Journal of African Studies 34(2), 2000, 337-74, 347-8. 
tackled in the case studies, it has to be questioned from the outset how 'ethnicity' can be imagined in its relation to the nation-building project, to 'racial' phenotypes, and to the political organisation of communities. ${ }^{2}$

As we have seen, the recourse to ethnic group mobilisation appears to be widespread in many of the recent conflicts in very different zones of subSaharan Africa. Moreover, in everyday life, individuals frequently refer to their own ethnic characteristics, and still more to those of 'strangers' and 'others'. The same individuals might make jokes about the 'typical' character of members of other ethnic groups; during elections they vote for candidates they regard as members of their own ethnic constituency; they tend to introduce themselves to visitors and conversation partners as part of the respective community. ${ }^{4}$ In this respect, it is difficult even for the most critical and 'constructivist' observer to discuss away ethnic allegiance as a factor in contemporary African societies, especially where the distribution of resources is at stake. For other parts of the world, the problem is not posed as such, with the exception, again, of 'native' communities of the Americas or 'tribal structures' in Asia.

Obviously, this observation does not give an answer to whether ethnicity, as a factor in community life, has long been such an important variable in group perceptions and a longstanding, historical problem in community relations. ${ }^{5}$ Also, in sub-Saharan Africa it has been a conceptual challenge that is hotly disputed by scholars. Today it is occasionally claimed that at least the academic conflict is more or less resolved. ${ }^{6}$ However, the attempts to formulate a coherent opinion or even a consensus on the historical role of ethnicity have not produced any more recent syntheses; all in all, there is still no broader analysis of the changes in African ethnic identification over time, or one that would include a view on ethniticy in other parts of the globe.

After nearly forty years of intense discussions, most scholars tend to use the concept of ethnicity as one variable regarding identifications of individuals,

2 Wallerstein, Immanuel, 'The Construction of Peoplehood: Racism, Nationalism, Ethnicity', in Etienne Balibar and Immanuel Wallerstein (eds.), Race, Nation, Class: Ambiguous Identities (London - New York: Verso, 1991, translation of orig. Paris: La Découverte, 1988), 71-85, 77-9.

3 Hargreaves, John D., 'From Strangers to Minorities in West Africa', Transactions of the Royal Historical Society 31, 1981, 95-113, 98-9.

4 De Jong, Ferdinand, 'A Joking Nation: Conflict Resolution in Senegal', Canadian Journal of African Studies 39(2), 2005, 389-413, 400-1.

5 Burgess, M. Elaine, 'The resurgence of ethnicity: myth and reality', Ethnic and Racial Studies $1(3), 1978,265-85,278-80$.

6 Nevertheless, as Carola Lentz argued, it is surprising how rapidly the frontlines reappear in some discussions, see Lentz, Carola, "Tribalism" and ethnicity in Africa: a review of four decades of Anglophone research', Cahiers des Sciences Humaines 31(2), 1995, 303-28, 307-8. 
and for group solidarity. However, there is no impetus anymore towards discussion, in broader designs, of the historicity of the phenomenon of ethnic solidarity, which continues to be little illuminated. ${ }^{7}$ Arguably, the most representative recent opinion (if seldom taken as the explicit point of reference) is presumably expressed in Bruce Berman's discussion on ethnic groups. According to Berman, most of Africa's ethnic labels existed already in the nineteenth century, that is, at the moment of colonial conquest, and probably earlier. However, they would have changed their meaning entirely, and their importance as a medium of group solidarity would have grown over the years. The crucial point in Berman's argumentation is probably the claim that none of the ethnic groups of post-colonial times had already been present $a$ s such (with an important function as regards group mobilisation) in the pre-colonial phase of sub-Saharan Africa. ${ }^{8}$ While thought-provoking, this idea is probably too simple: both P.E.H. Hair's and Walter Rodney's studies make it clear that many of the labels had a meaning for group organisation before 1850 - and if it was structurally different, one would need need to ask what the difference was. ${ }^{9}$

In any case, nowadays a number of studies, frequently through the employment of a micro-perspective, refer to a rather flexible interpretation of ethnicity as a factor of group identification. The scholars in question discuss evolutions inside particular groups, which in the post-colonial period are understood (and describe themselves) as ethnic groups. They claim that the experiences of the respective communities are flexible ones, and they attribute much of the process of developing larger and more cohesive group identifications to the necessities of frequently complicated conflicts and alliances, increased by the insecurities of resource distribution in the post-colonial states. According to such a perspective, ethnicity becomes both a previously existing concept of group solidarity, and a particular tool in concrete situations of group conflict. This interpretation does not really explain the motives and the context for the use of ethnic solidarity instead of other emotional affiliations. Nonetheless, on the widely agreed platform of such a compromise, the once-impulsive scholarly debates about ethnicity have become far less aggressive.

This had indeed been very different in the 1970s and 1980s. It is useful to recall the origins of the debate, as this enhances our understanding of the

7 Scherrer, Christian P., Ethnicity, Nationalism and Violence: Conflict management, human rights, and multilateral regimes (Aldershot - Burlington: Ashgate, 2003), 50-3.

8 Berman, Bruce, 'Ethnicity, Patronage and the African State: the Politics of Uncivil Nationalism', African Affairs 97(388), 1998, 305-41, 325-6.

9 Hair, 'Continuity;' Rodney, Walter, A History of the Upper Guinea Coast 1545-180o (Oxford: Clarendon Press, 1970). 
crucial issues still at stake in current discussions about ethnic identification. In fact, the debate was in part so extraordinarily heated due to the particular colonial legacy in anthropology (with its effects on historical studies). In this context, the constructivist view was a sharp attack against research positions that had remained influential in the first phase after the independence of most colonial territories. Although to a lesser degree, the disciplines of history and sociology also became entangled in the debate.

Many of those European researchers, who had started to work under the financially well-equipped late colonial administrations of the 1940s and 1950s, shared a number of common scientific ideas (or working hypotheses) about African and other 'tribal' populations. These ideas were thus linked to the 'ideological' background of colonial rule. In part, they conformed to the approaches of European administrators who had been engaged in classifying groups to facilitate their own administrative work. ${ }^{10}$

The basic assumption that, in Africa and 'tribal Asia', identity was mostly related to 'tribal' solidarities remained for colonial administrations one essential basis of relations with such populations. As a basis for defining Africans and 'tribal Asians', it encouraged the analysis of their group organisation according to seemingly reliable 'tribal' characteristics. Modernisation, and the introduction or strengthening of principles of capitalist economy in local communities, seemed to have an impact on those 'tribal' structures, but, still, the latter were considered as essential and stable. ${ }^{11}$ The employment of the expression 'ethnicity' (as an alternative to 'tribal' or 'tribe') starts only in the 1940s and in the early phase of the discussion, the meaning of this expression is blurred. Not until the 1970s did 'ethnicity' develop into a 'pertinent category' in the broader debate about group relations in sub-Saharan Africa, and other regions where research on regional groups was carried out. ${ }^{12}$

Other factors were soon pointed out as having an influence in the consolidation of ethnic ties, but the interrelations were rarely explained. ${ }^{13}$ Religion was often understood as such a factor: it stands either in competition with other, including ethnic, solidarities; or it can claim universal adherence, trying (under

10 This is reflected in works like Kirk-Greene, A.H.M., 'The Peoples of Nigeria: The Cultural Background to the Crisis', African Affairs 66(262), 1967, 3-11, 5 .

11 Balandier, Georges, 'Structures sociales traditionnelles et changements économiques', Cahiers d'Etudes Africaines 1(1), 1960, 1-14, 6-7.

12 Poutignat and Streiff-Fenart, Théories, 22, 24-6.

13 Berman, Bruce; Dickson Eyoh, and Will Kymlicka, 'Conclusion: African Ethnic Politics \& the Paradoxes of Democratic Development', in Bruce Berman, Dickson Eyoh, and Will Kymlicka (eds.), Ethnicity and Democracy in Africa (Oxford: James Currey - Athens/он: Ohio University Press, 2004), 317-23, 318. 
most conditions with little success) to make other forms of allegiance disappear. In certain cases, religions appeared to be a vehicle for ethnic groupbuilding, and in some occasions they even offered a lever for ethnic change. ${ }^{14}$ Regarding the many existing African religions, it was not only the conversion to Islam or Christianity that made such a fundamental impact. Some other, more local religions also had a significant impact on group identifications. As in the case of the cult of Tongnaab in northern Ghana, new followers of local religions took other ethnic labels. ${ }^{15}$

Professional situation and the related status position is another category that might overlap with ethnic sentiment: effectively, where 'ethnicity' is employed as a concept to describe situations of migration, it has been argued by sociologists that the disappearance of professional and status difference contributes to a diminution of ethnic tensions. ${ }^{16}$ Migration, mainly from rural into urban contexts, can have an influence on the ethnic self-perception of an individual: this problem, which had already been discussed by colonial officials, also became an early standard subject for anthropologists working on sub-Saharan Africa. ${ }^{17}$

'Tribes', as a central category for early anthropologists, were mostly regarded as static units. The 'primordialist' view treated the members of those groups as inevitably connected, although it usually remained undiscussed whether this bond was to be explained through 'genetic' links, or through a centuries-long experience of 'cultural' unity. ${ }^{18}$ Anthropology and colonial administration interacted strongly in this process of creating the image of timeless communities. ${ }^{19}$

14 Devisse, Jean, 'Islam et ethnies en Afrique', in Jean-Pierre Chrétien and Gérard Prunier (eds.), Les ethnies ont une histoire (second edition, Paris: Karthala, 2003), 103-15, 110-2; Brown, Graham K., 'Legible Pluralism: The Politics of Ethnic and Religious Identification in Malaysia', in Joseph Ruane and Jennifer Todd (eds.), Ethnicity and Religion: Intersections and Comparisons (London - New York: Routledge, 2011), 31-52.

15 Allman, Jean, and John Parker, Tongnaab: The History of a West African God (Bloomington - Indianapolis: Indiana University Press, 2005), 144.

16 Hechter, Michael, 'The political economy of ethnic change', American Journal of Sociology 79(5), 1974, 1151-78, 1176.

17 Gluckman, Max, 'Tribalism in Modern British Africa', Cahiers d'Etudes Africaines 1(1), 1960, $55^{-70}, 57^{-8}$.

18 Alonso, 'Politics', 392; Zolberg, Aristide R., 'The Structure of Political Conflict in the New States of Tropical Africa', American Political Science Review 62(1), 1968, 70-87, 73-4. These positions link to older anthropological theory, such as that of Lévi-Strauss, Claude, Race et Histoire (Paris: Denoël, 1987 [1952]), 19-23; Van den Berghe, Pierre L., The Ethnic Phenomenon (New York - Oxford: Elsevier, 1981), 20-7.

19 Miller, Joseph C., 'History and Africa/Africa and History', American Historical Review 104(1), 1999, 1-32, 15 . 
European officials, at least the ones who were more interested in crafting an 'adequate' administration of colonial populations, took much of the information they utilised for local governance from the work of early anthropologists. Those results contributed in colonial Africa to an administrative worldview, in which the ethnic affiliation of the African subjects was a key variable. It was a particularly prominent concept when those officials discussed the practical organisation of the territories, and whenever they attempted to make local structures more 'authentic'.

A large percentage of the European administrators believed themselves to be facing homogeneous 'tribes', and they became used to simply taking them as a reality. However, a form of administration that was based in theory on the principle of ethnic ('tribal') categorisation, suggested the use of specialists in anthropology. In the interwar period and under the late colonial states, colonial governments financed a growing number of missions of anthropologists that were to study the structures and 'customs' of certain circumscribed groups. The authority of these scholars gave further strength, of course, through the practice of their work in the field, to the idea of the African continent and some parts of Asia as worlds of 'tribes. ${ }^{20}$ In turn, European officials gladly 'profited' from the fresh information on the subject, and built on more recent interpretations offered by the specialists. In these ways, colonial anthropology also had an impact on political organisation in sub-Saharan Africa: based on anthropological results, administrators attempted, for example, to limit the number of candidates for chieftaincies - as structures of 'indirect rule' - to 'eligible candidates', who belonged to the right 'tribe' and 'traditional' family, according to the rules and customs of the 'tribe'.21 The close relation between the administrative and the academic sector guaranteed the dominance of the 'primordialist' view until the decade of the 196os, and it also appeared to be destined to shape the newly emergent scholarly field of African history. ${ }^{22}$

20 See the sublime analysis of Ekeh, Peter P., 'Social Anthropology and Two Contrasting Uses of Tribalism in Africa', Comparative Studies in Society and History 32(4), 1990, 660-700, 662-6.

21 Waller, Richard, 'Acceptees \& Aliens: Kikuyu Settlement in Maasailand', in Thomas Spear and Richard Waller (eds.), Being Maasai: Ethnicity \& Identity in East Africa (Oxford:James Currey - Dar-es-Salaam: Mkuki Na Nyota - Nairobi: EAEP - Athens/o H: Ohio University Press, 1993), 226-57, 237-42.

Mercier, Paul, 'Remarques sur la signification du "tribalisme" actuel en Afrique noire', Cahiers Internationaux de Sociologie 31(2), 1961, 61-80, 78-9; Gluckman, Max, Order and Rebellion in Tribal Africa (London: Cohen and West, 1963), 223-4; Stevenson, Robert F., Population and Political Systems in Tropical Africa (New York - London: Columbia University Press, 1968), 160-87; Van Velsen, J., The Politics of Kinship: A Study in Social Manipulation among the Lakeside Tonga of Nyasaland (Manchester: Manchester University Press, 1964), 6-7. 
In 1961, the respected specialist of Togolese history - and former district administrator in Togo - Robert Cornevin could still write that 'The black person of Africa feels spontaneously the value of the history of his ethnic group. ${ }^{23}$ Within the historiography of various world regions, this position was doubtlessly strongest for the African continent, while for West Asia, Central Asia, the Indian sub-continent, and especially China, historians focused more rapidly on the nation-state projects, and ethnic groups were regarded as unmodern minorities. ${ }^{24}$

As we have seen, the 1970s and 1980s marked a change in the scientific study of group organisation in sub-Saharan Africa. This change led to the dominance of a 'constructivist' perspective, according to which both agents of the colonial power and African political leaders with a clear interest in gaining and maintaining the control of potential followers, had a stake in the creation (or, ulitimately, 'invention') of ethnic groups. ${ }^{25}$ By the 1960 s, some scholars were pointing to the flexibility of ethnic self-assertions, particularly again in the case of migration to urban centres, where for the sake of local protection, individuals were observed to sometimes turn to members of other 'tribes', building patronage networks independently from ethnic solidarity. ${ }^{26}$ In 1970, Aidan Southall argued that many groups in sub-Saharan Africa and 'tribal Asia' did not conform to the classical criteria of 'tribe', as those solidarities had not existed before in their own and their neighbours' perception. In accordance with this particular vision, ethnic groups had only come into being during the colonial period as a response to certain problems. ${ }^{27}$ However, scholars still distinguished between a de facto core of ethnic identification, and parts that could be more easily manipulated. ${ }^{28}$

23 Cornevin, Robert, 'L'Histoire des Peuples de L'Afrique Noire: Branche de L'Ethnologie ou Science à Part Entière?', Journal of African History 2(1), 1961, 15-23, 19.

24 McCarthy, Susan, Communist Multiculturalism: Ethnic Revival in Southwest China (Seattle - London: University of Washington Press, 2009), 37-8.

25 Bierschenk, Thomas, 'Rituels politiques et construction de l'identité ethnique des Peuls au Bénin', Cahiers des Sciences Humaines 31(2), 1995, 457-84, 474-7.

26 Wallerstein, Immanuel, 'Ethnicity and National Integration in West Africa', Cahiers d'Etudes Africaines 1(3), 1960, 129-39, 133; Sandbrook, Richard, 'Patrons, Clients, and Factions: New Dimensions of Conflict Analysis in Africa', Canadian Journal of Political Science 5(1), 1972, 104-19, 115-8.

27 Southall, Aidan W., 'The Illusion of Tribe', Journal of Asian and African Studies 5(1-2), 1970, 28-50, 34-5.

28 Mitchell, James Clyde, 'Perceptions of Ethnicity and Ethnic Behaviour: An Empirical Explanation', in Abner Cohen (ed.), Urban Ethnicity (London: Tavistock, 1974), 1-35, $15^{-20 .}$ 
The discussions of the 1970s were the first step in the reversal of research positions on ethnic identification, and this reconfiguration had a clear focus on the African continent. ${ }^{29}$ This was followed by the impact of the books of Amselle and M'Bokolo during the 1980s: their arguments shattered the 'primordialist' position. ${ }^{30}$ The latter was pushed onto the defensive and nearly unable to respond for a period. The existence of primary affinities and the automatic affectivity of individuals to members of groups identified as ethnic peers was apparently refuted. ${ }^{31}$ However, even under these unfavourable circumstances, the 'primordialist' view on ethnic sentiment was not entirely defeated; moreover, during the whole of the 1980 s, it notably continued to retain its hold over public discussions in the media, where the same images of irrationality and 'savageness' continued to prosper, especially for Africa, but also for some Asian regions. ${ }^{32}$ With more academic impact, it also continued to dominate over parts of research in political science. ${ }^{33}$ These facts only added to the vigorousness of 'constructivist' critique. The aggressiveness of the debate made even more moderate formulations of 'primordialist' views unacceptable.

'Constructivist' scholars often attempted to link their arguments to other contemporary debates, such as around clientelism and migration contexts. Wherever particular importance is given to the impact of client-patron networks - which, in view of their social and economic role, are an essential category particularly in both colonial and post-colonial African regions, and probably also under pre-colonial conditions - this could be connected to the creativeness of ethnocultural solidarities. In fact, René Lemarchand had already in the 1970s interpreted ethnocultural ties as a translation of patronclient relationships. ${ }^{34}$

29 Gallagher, Joseph T., 'The Emergence of an African Ethnic Group: the Case of the Ndendeuli', International Journal of African Historical Studies 7(1), 1974, 1-26, 1-3.

30 Southall, Aidan W., 'The Ethnic Heart of Anthropology', Cahiers d'Etudes Africaines $25(100), 1985,567-72,572$.

31 Eller, Jack David, and Reed M. Coughlan, 'The poverty of primordialism: the demystification of ethnic attachment', Ethnic and Racial Studies 16(2), 1993, 183-202, 195-6.

Campbell, Aidan, 'Ethical Ethnicity: A Critique', Journal of Modern African Studies 35(1), 1997, 53-79, 57-60; Vanhanen, Tatu, 'Domestic Ethnic Conflict and Ethnic Nepotism: A Comparative Analysis', Journal of Peace Research 36(1), 1999, 55-73, 66.

Collier, Paul, and Anke Hoeffler, 'On the Incidence of Civil War in Africa', Journal of Conflict Resolution 46(1), 2002, 13-28, 22; Bates, Robert H., 'Ethnicity and Development in Africa: A Reappraisal', African Economic Review 9o(2), 2000, 131-4, 134.

Lemarchand, René, 'Political Clientelism and Ethnicity in Tropical Africa: Competing Solidarities in Nation-Building', American Political Science Review 66(1), 1972, 68-90, 69-70; Isaacman, Allan, and Derek Peterson, 'Making the Chikunda: Military Slavery and Ethnicity 
A very different contribution came from researchers writing about 'ethnicity' as a category during migration - in which the variable had a distinct sense. ${ }^{35}$ The first generation of scholars who were engaged in this field normally worked on the sociology of migration in so-called industrial countries. They came, nonetheless, to some substantially similar results concerning ethnocultural sentiment. Hence, in relation to the classic country of migration studies, the United States, scholars argued that the awareness of ethnic links rose in particular periods. ${ }^{36}$ For example, Cuban exiles migrating into the us in the 1960 appeared to underline their Cuban ethnicity only from the 1970s onwards, to obtain socioeconomic advantages. (As I will discuss below, it is questionable whether a scholar working on sub-Saharan Africa would accept 'Cuban' as an appropriate ethnic category, but for the sociology of migration such data as given by interviewees is widely accepted.) ${ }^{37}$ Another alternative in those migration contexts, however, was to seek joint group identities with other communities, so that different origins were fused into a common identification and led to a new ethnic sentiment in its own right. This describes the classic case of 'Hispanic identity' in North America, which is mirrored in other cases of immigrant groups. ${ }^{38}$ Such phenomena, typical for ethnicity in migration contexts, are much more rarely documented for sub-Saharan Africa. ${ }^{39}$ It is unsurprising that ethnicity as a category in global historical studies on migration, such as in settler colonies, also functions in the same sense. ${ }^{40}$ However, the global historical debate on migration was based on an idea of groups that left very much open when and why the classification as 'ethnic group' was ultimately adequate. ${ }^{41}$

in Southern Africa, 1750-1900', International Journal of African Historical Studies 36(2), 2003, 257-81, 263-4, and, Newitt, Malyn, 'Kinship, Religion, Language and Political Control: Ethnic Identity among the Peoples of the Zambesi Valley', in Alexander Keese (ed.), Ethnicity and the long-term perspective: the African experience (Berne: Peter Lang, 2010), 67-92, 88-9.

35 Francis, E.K., Interethnic Relations: An Essay in Sociological Theory (New York - Oxford Amsterdam: Elsevier, 1976), 172-89.

36 Modood, Tariq, 'Multiculturalism, Ethnicity and Integration: Some Contemporary Challenges', in Tariq Modood and John Salt (eds.), Global Migration, Ethnicity and Britishness (Basingstoke - New York: Palgrave Macmillan, 2011), 40-62.

37 Portes, Alejandro, 'The rise of ethnicity', American Sociological Review 49(3), 1984, 383-97, 386.

38 Nelson, Candace, and Marta Tienda, 'The structuring of Hispanic ethnicity: historical and contemporary perspectives', Ethnic and Racial Studies 8(1), 1985, 49-74, 53.

39 Hirst, Michael A., 'Tribal Migration in East Africa: A Review and Analysis', Geografiska Annaler, Series B, 52(2), 1970, 153-64, 163.

40 Bashford, Alison, 'Immigration restriction: rethinking period and place from settler colonies to postcolonial nations', Journal of Global History 9(1), 2014, 26-48, 45 .

41 Manning, Patrick, Migration in World History (New York - London: Routledge, 2005), 4, $103-5$. 
In the 1990s, some attempts were made to find a conclusion for the debate around ethnicity. Various scholars insisted that while ethnic groups were originally invented, they now constitute a strong reality. ${ }^{42}$ Even with the invention of group identifications in the colonial period, they claim that 'the historicity does not diminish the reality'. As for the Taita of Kenya, Bill Bravman defended the interpretation that, under particular circumstances, groups (including Africans) created a necessary feeling of community, expressing it through formulations of ethnic sentiment. ${ }^{43}$ For other geographical zones, like the Upper Volta region, scholars hold that, while ethnic labels existed before 1850, ethnicity was, between the second half of the nineteenth century and the 1920s, no vital criterion, and did not lead to alliances between village communities. ${ }^{44}$ Mahir Şaul and Patrick Royer argue that, at least in this broader region, descent groups were usually 'multi-ethnic', 'ethnicity itself was unstable', and that 'we simply do not know what labels such as "Bobo", "Marka", or "Bwa" might have meant at that time. 45

However, while the tone of the debate has become less aggressive, many scholars maintain the idea of a dominant role that (colonial) invention had in the formation of ethnic solidarity especially in Africa. This is well exemplified by Gerald Wright's latest article on colonial manipulation. According to Wright, formulating group identities was a complicated process in which, however, ethnic arguments were negligible before the nineteenth century. Concerning the Gambia River region, he holds that many individuals now defining themselves as part of the 'Mandinka tribe' refer in their self-identification to the results of European studies from the colonial period. Thereby, they accept a label found for them by Europeans and even read the products of older, mostly

42 Bayart, Etat, 76-8; Berman, Bruce; Dickson Eyoh, and Will Kymlicka, 'Introduction: Ethnicity \& the Politics of Democratic Nation-Building in Africa', in Bruce Berman, Dickson Eyoh, and Will Kymlicka (eds.), Ethnicity and Democracy in Africa (Oxford: James Currey - Athens: Ohio University Press, 2004), 1-21, 3.

43 Bravman, Bill, Making Ethnic Ways: Communities and Their Transformations in Taita, Kenya, 1800-1950 (Portsmouth/NH: Heinemann - Nairobi: EAEP - Oxford: James Currey, 1998), 14. See also: Gordon, David M., 'History on the Luapula Retold: Landscape, Memory and Identity in the Kazembe Kingdom', Journal of African History 47(1), 2006, 21-42, $35^{-7}$.

44 Colleyn, Jean-Paul, and Danielle Jonckers, 'Ceux qui refusent le maitre, la conception du pouvoir chez les Minyanka', Africa 53(4), 1983, 43-58, 52-3.

45 Şaul, Mahir, and Patrick Royer, West African Challenge to Empire: Culture and History in the Volta-Bani Anticolonial War (Athens/oH: Ohio University Press - Oxford: James Currey, 2001), 15-6. 
European and North American, scholarship in order to refine their own 'traditional' accounts on group experiences. ${ }^{46}$

Carola Lentz offers a more balanced conclusion. She argues in her overview of tendencies in the debate on ethnicity that it now seems to be obvious that ethnic labels were not purely invented under colonial rule, although the colonial impact had certain distinguishable effects. Social inequalities induced by the colonial rulers, the work of cultural brokers between European administrations and local populations, and the tendencies towards more essentialism as provoked by the integration of interested groups of persons into structures of collaboration and 'indirect rule', all seem to have contributed to the local fixation on ethnic identifications. In this context, Lentz comments that certain conditions made the maintenance of those modified group identifications attractive for individuals and group leaders, and that this did not only happen under colonial rule. ${ }^{47}$

Other scholars also emphasised that while ethnic labels are constantly used, they can, nonetheless, easily be changed. In cases when they suit the individual, such switches of identification appear rather often. For example, some individuals claim at a given moment never to have belonged to a certain group, although their migration background from a particular region seems to be obvious. Examples of this type might be cited from a large number of African regions and related studies, and have been amply discussed for Gikuyuspeakers ('Kikuyu') settling in or close to Maasai communities in Kenya. ${ }^{48}$

A 'softer' variant of this position towards the construction of ethnic identification refers to processes of 'assimilation' and to the permeability of groups. This perspective does not entirely discard the idea of distinguishable ethnic entities 'existing before', but holds that they became activated under specific circumstances, namely in frontier situations. This position was quite early formulated by Fredrik Barth, who held that, from the anthropologist's point of view, the decisive criterion for group cohesion should not be the range of cultural elements defining the group from inside, but its boundaries with neighbouring communities. In this perspective, borders between groups are

46 Wright, Donald R., "'What Do You Mean There Were No Tribes in Africa?": Thoughts on Boundaries - and Related Matters - in Precolonial Africa', History in Africa 26, 1999, 409-26, 420-1.

Lentz, Carola, “Tribalismus" und Ethnizität in Afrika - ein Forschungsüberblick', Leviathan 23, 1995, 115-45, 134-5.

48 Galaty, John G., “The Eye that Wants a Person, Where Can It Not See?" Inclusion, Exclusion \& Boundary Shifters in Maasai Identity', in Thomas Spear and Richard Waller (eds.), Being Maasai: Ethnicity \& Identity in East Africa (Oxford: James Currey - Dar-es-Salaam: Mkuki Na Nyota - Nairobi: EAEP - Athens: Ohio University Press, 1993), 174-94, 188-9. 
permeable when it comes to individuals.$^{49}$ Newer studies on 'borderlands' do not directly follow the perspective of Barth, as they do not regard boundaries as either division lines or permeable membranes, but focus on the creative use of the border to the advantage of populations on both sides and on the creation of 'borderland identities.' ${ }^{50}$ By contrast, Barth's position finds an echo in other fields of research from the 1990s. ${ }^{51}$

As we can see from those discussions, colonial simplification is definitely only one part of the picture of ethnic group-building. Today, the 'primordialists' certainly have more to say than just repeating colonial 'knowledge. 52 Moreover, their position continues to correspond more strongly to the contemporary visions expressed by African and other 'tribal' populations. In the post-colonial period, it would be unusual to meet locals who would admit that their group of reference has changed its ethnic allegiance over the decades. If one takes at face value the accounts of interviewees, the 'primordialist' perspective appears as natural. ${ }^{53}$ Informants tend to give versions in which, normally, they themselves and their forefathers have never modified their identity. Only language and religion are potentially changeable; ethnocultural sentiment, on the contrary, appears to be immutable. This means we still find an undiscussed (but important) contradiction between the dominant perspective on identity elaborated by most researchers - a vision of ethnicity as largely crafted and flexible, albeit ultimately linked to local modalities - and the results won through a principal methodological tool that scholars on African societies tend to employ. To formulate it the other way round: 'constructivists' who rely on contemporary oral interviews are likely to come up with results that contradict their expectations.

However, while the grounds for giving a clear definition of concepts of ethnic solidarity are extremely shaky, I will nonetheless attempt to formulate a

49 Barth, Fredrik, 'Introduction', in Fredrik Barth (ed.), Ethnic Groups and Boundaries: the social organization of cultural difference (Bergen: Univ. Forl., 1969), 9-38.

$50 \quad$ Nugent, Smugglers, 272-3; Saïbou, Issa, Ethnicité, frontières et stabilité aux confins du Cameroun, du Nigeria et du Tchad (Paris: Harmattan, 2012).

51 Wimmer, 'Strategies', 1038-41; Lamphear, John, 'Aspects of 'Becoming Turkana': Interactions \& Asmilation Between Maa- \& Ateker-Speakers', in Thomas Spear and Richard Waller (eds.), Being Maasai: Ethnicity \& Identity in East Africa (Oxford: James Currey - Dar-es-Salaam: Mkuki Na Nyota - Nairobi: EAEP - Athens/o H: Ohio University Press, 1993), 87-104, 92-5.

$52 \quad$ Poutignat and Streiff-Fenart, Théories, 101.

53 Williams Jr., Robin M., 'The Sociology of Ethnic Conflicts: Comparative International Perspectives', Annual Review of Sociology 20, 1994, 49-79, 58. 
working definition. ${ }^{54}$ Given the strongly varying forms of employment of the category, this definition needs to be congruent with the latest results of scholarship, but avoid the larger debate on so-called 'ethnicity' of migrant communities. This definition necessarily has a 'constructivist' note: because what individuals claim to be plays an important role in the creation of solidarity which is obviously not the only criterion of belonging, but cannot simply be left out of the discussion. Ethnic groups can be described as self-declared communities whose spokesmen define them as groups with a common history and traditions, and who cling to this common identification independently from state structures and institutions. By contrast, a sentiment relying on political institutions is also imaginable and may in the widest sense be called 'state patriotism', or, if the relationship between the largest existing political structure and the population within its borders is the central factor of identification, may refer to the equally vague concept of 'nation'. Ethnocultural solidarity exists, however, independently of the state; on the one hand, its implications are thus narrower than those of the inhabitants of particular (and, ultimately, reasonably 'successful') states that have, as a group, become somewhat galvanised into a broader community identification. On the other hand, ethnic solidarity thus defined supersedes the frontiers of the village and kinship level, and is normally abstract from the level of the family: one village community would usually not be sufficient to circumscribe an ethnic identification, and in many cases the local identification as translated through village solidarity, rivals rather than supports ethnicfeelings. The crucial role of self-representation during encounters explains why my study is especially interested in the exchange between groups and the colonial powers.

Ethnic solidarity as defined by the accounts given by individuals is in most cases reinforced through certain cultural factors, although this picture is complicated. ${ }^{55}$ Certainly, the most important markers of ethnic identification tend to change from community to community, and even within communities. ${ }^{56}$ Language is one typical basis for inducing an ethnocultural community sentiment: most communities claiming ethnic solidarity have one idiom. Nonetheless, not every linguistic group is an ethnic group, and this criterion is

54 De Vos, George, and Lola Romanucci-Ross, 'Ethnicity: Vessel of Meaning and Emblem of Contrast', in George De Vos and Lola Romanucci-Ross (eds.), Ethnic identity: Cultural Continuities and Change (Palo Alto: Mayfield, 1975), 363-90, 364 .

55 Banton, Michael, 'The sociology of ethnic relations', Ethnic and Racial Studies 31(7), 2008, 1267-85, 1275 .

56 Mahmood, Cynthia K., and Sharon L. Armstrong, 'Do ethnic groups exist? A cognitive perspective on the concept of cultures', Ethnology 31(1), 1992, 1-14, 9 . 
not obligatory for constituting ethnic solidarity: in particular, the spectacular case of Rwanda provides an important counter-example, where language difference was not at stake.

Cultural forms and types of behaviour, such as common institutions of organisation, festivals, folklore like dances or songs, professional particularities, marriage patterns, or architecture can obviously contribute to ethnic solidarity. They are frequently commented on whenever group leaders explain the nature of their ethnic community, but their existence is not crucial for the identification. These elements are thus important whenever a dominant discourse within the group identifies them as crucial, not, as older anthropological research has tended to make us believe, automatically. More important is the question of historical tradition, which is always more or less invented, but gives legitimacy to the feeling of unity inside the community, and the idea of a common destiny. I insist that such a definition is useful for a global historical perspective, and not at all only for sub-Saharan Africa or 'tribal Asia'. Its use challenges the view according to which the concept is irrelevant in the 'western world', without conceding to the view of the historians of global migration, who often do not find any distinction between 'ethnic group' and 'nation'.

During the decades of colonial rule, anthropologists tended to link the category of 'tribe' to physical attributes. Even with the colonial bias in studies of ethnicity attacked by contemporary scholarship, those ideas continue to circulate and to play a role in public debates both in the former metropoles, in the international media, and in African societies. The notion of 'race', however, also plays another role in the African context in particular. Under colonial rule, opinion leaders in different African societies attempted to forge a pan-African identity, and under those conditions, questions of both 'race' - as a common element for the colonial subjects - and 'ethnicity' - described as 'tribalism', and as the main obstacle to the objective of African unity - were discussed as diametrically opposed.

\section{Race}

'Race' is a category that according to its variable definitions overlaps with 'ethnicity' in many popular, but also in some scientific, contexts of discussion. ${ }^{57}$ Categorisation by the criterion of 'race', in the sense of a fictitious, phenotypebased category, gains importance by being an essential problem of relations between colonial rulers and ruled populations during the period of European domination. Moreover, 'racial issues' were sometimes employed to minimise 
inter-group conflicts through the definition of scapegoats, which tied together, for a normally limited period, the members of hostile groups.

Racial conflict is especially typical for sub-Saharan Africa under colonial rule insofar as it defines in large parts the relations between colonisers and colonised elements inside the system. It obtained a particular and very aggressive meaning whenever the colonial encounter involved frequent contact situations between African populations and European settlers. This factor is less important for the populations of West Africa, where European settlement was uncommon. The inter-community conflicts between West African populations compared in this book, cannot be described as conflicts characterised by the phenotype of the individuals concerned. Members of one group were not able to identify those of a different and, ultimately, hostile group through the latter's physical appearance (although they might sometimes believe they could). ${ }^{58}$

In the interior of West Africa, we nonetheless find some regions in which 'racial' conflicts exist. In parts of the Sahel zone, where 'mixed' populations with different skin colourings are neighbours, 'Moorish' populations in Mauritania and part of the Tuareg communities in Mali and Niger, are defined as 'white' population groups. ${ }^{59}$ However, apart from several itinerant clerics who enjoyed considerable respect among Muslims in West Africa, members of those groups did not appear in West Africa's coastal regions.

'Race' as a concept of categorisation plays a role both for reasons of terminology, and for the above-mentioned fact that 'racial issues' could be utilised to bridge existing conflicts between West African communities. The first point will bring us back to the pitfalls of theory. I have already highlighted the problem of overlapping categories of identifications: since in migration contexts and migration studies regarding Europe and the Americas, 'ethnicity' is now sometimes equated to skin colour, it is important to make these distinctions. Linking our discussion to broader and global questions of belonging and identification, 'race' is indeed a complex element of distinction and mobilisation. Its relationship to ethnocultural sentiment is remarkably variable. On the one hand, elements perceived as 'racial', which are normally expressed by skin colour, can support perceptions of ethnic difference.${ }^{60}$ On the other hand,

$5^{8}$ These alleged genetic differences as reflected in phenotype are still presented as a matter of fact in older, pre-genocide literature; see: Van den Berghe, Phenomenon, 29.

59 Féral, Gabriel, 'Administrations comparées en pays nomade', in Edmond Bernus, Pierre Boilley, Jean-Louis Triaud and Jean Clauzel (eds.), Nomades et commandants: administration et sociétés nomades dans l'ancienne A.O.F (Paris: Karthala, 1993), 105-12, 111.

6o Other (constructed) physical-biological categories, like racial 'odour', could be added to these imagined differences, see Beer, Bettina, 'Geruch und Differenz: Körpergeruch als Kennzeichen konstruierter "rassischer” Grenzen', Paideuma 46, 2000, 207-30, 221-3. 
'race' can be understood, in a way, as an alternative concept to ethnicity. A 'racial' perspective frequently excludes the existence of smaller ethnic identifications and facilitates more global interpretations.

The very notion of 'race' as a factor of distinction is frequently imprecise. In some cases, so-called 'racial' aspects overlap with issues of 'ethnicity', often in ways that make it complicated to distinguish well between the employments of the two terms. This has had a strong impact on academic analysis, in particular on sociological studies. It is also mirrored in the everyday use of the word 'ethnic minorities', which frequently refers to coloured immigrants in European countries and even to Afro-Americans in the case of the United States. The terminological problems imported with such a methodological concept, whenever it is used in a context of immigration (or for migration studies), are easily understandable: they lead us into situations in which, for example, Americans or Europeans with African descent are defined as an 'ethnic minority' or 'ethnic group'. From a perspective of categories, this is highly problematic. In the North American case, the African origins of the individuals concerned are usually, of course, at a distance of at least two centuries, and the 'Afro-Americans' imagined as an 'ethnic minority' do not, furthermore, really have common cultural characteristics, their own language, or historical traditions (although, obviously, the latter are sought in revivalist movements). For historians it should be absurd that the 'Afro-American' community is defined as an 'ethnic group', with skin colour as the near-exclusive criterion of distinction, ultimately paired with a group history of particular social differences that is, however, unlikely to be a convincing element of any possible ethnic group identification. ${ }^{61}$

Furthermore, one needs to question the values conveyed by the term 'race', even if this term is employed in a purely academic sense. Indeed, this category is inappropriate as it relates to imagined characteristics seen as typical for a group of a particular skin colour. We thus need, obviously, to strictly apply it in terms of phenotype, describing visible physical characteristics of a person that are perceived by others and considered by them to be 'racial. ${ }^{62}$ The term as I employ it, as expressing an element that can cause a certain amount of group affiliation through perceived otherness, describes a basis of racist hostility, which is legitimised through both visible and imagined bio-physical distinctions.

Occasionally, those 'racial' definitions have enjoyed a considerable influence in the argumentation of elite groups, both of the European rulers formulating

61 See a discussion of this problem in Aronson, Dan R., 'Ethnicity as a Cultural System: an Introductory Essay', in Frances Henry (ed.), Ethnicity in the Americas (The Hague: Mouton, 1976), 9-19, 13-5.

62 Nayak, Anoop, 'After race: Ethnography, race and post-race theory', Ethnic and Racial Studies 29(3), 2006, 411-30, 411, 414, 419. 
a doctrine of superiority, and, in the case of the African populations, as a forceful counter-mobilisation. With respect to the African 'racial argument', this perception related to the experiences of African visitors going to Europe in greater numbers from the late nineteenth century. Originally, those visitors had mostly arrived as missionary students and guests, but, later on, a small number became enrolled as more or less regular students at European public universities. Those Africans were confronted with racial definitions in the metropoles, and they developed a strong self-perception of being entirely different from the colonial rulers. The experiences followed established patterns: from the beginnings of the Atlantic slave trade, European merchants had sent their Eurafrican offspring to Europe in order to give them a (Christian) education, and these were soon accompanied by the sons of some African traders. ${ }^{63}$

However, from the second half of the nineteenth century, the group of African residents in different European contexts became substantially larger. As students coming from the African continent were frequently concentrated in restricted areas, this created a sort of pan-African experience of living in Europe. Such an experience was closely related to hostilities that those migrants faced in their transitional living environment because of their skin colour. ${ }^{64}$ Therefore, Africans having lived in Europe were more eagerly ready to take a pan-African perspective - in ways that individuals from various parts of Asia did not experience. From the first half of the twentieth century, those impressions increasingly led to situations in which, confronted with the colonial systems, individuals defined themselves principally as 'African.65 It is no surprise that after the Second World War, under the impact of the wave of colonial reformism, African student organisations in Europe, such as the famous Fédération des Etudiants d'Afrique Noire en France (FEANF), became the most ardent supporters of the idea of a pan-African liberation. They formulated far more radical positions than the 'nationalists' who had lived permanently in their African countries. ${ }^{66}$

63 Northrup, David, Africa's discovery of Europe: 1450-1850 (Oxford: Oxford University Press, 2002), 147-9; Pasquier, Roger, 'Un Explorateur Sénégalais: Léopold Panet, 1819?-1859, African Historical Studies 2(2), 1969, 307-17, 313-4.

64 Bah, Thierno, 'Les étudiants de l'Afrique noire et la marche à l'indépendance', in CharlesRobert Ageron and Marc Michel (eds.), L'Afrique noire française: l'heure des Indépendances (Paris: CNRs Editions, 1992), 41-56.

65 Derrick, Jonathan, Africa's 'Agitators': Militant Anti-Colonialism in Africa and the West, 1918-1939 (London: Hurst, 2008), 91-7.

66 Benoist, Joseph-Roger de, 'FEANF and the colonial authorities', in UnESCo (ed.), The role of African student movements in the political and social evolution of Africa from 1900 to 1975 (Paris: UNESCO, 1994), 109-21. 
From the European point of view, the definition of Black Africans as 'alien beings' had been a typical phenomenon during the whole of the early modern period. Such alienation was sometimes probably only instrumental: it justified enslavement, and somehow legitimised the fact that Christian European planters imported, exploited, mistreated and killed Black African slaves in ways that were mostly unimaginable in European countries. The tremendous expansion of the practice of slavery within the plantation zones of the Americas posed a moral problem which needed to be resolved. ${ }^{67}$ The practice of denigrating Black Africans as the literal offspring of early biblical sinners made sense in this context: it allowed the European sellers and owners to regard the enslavement of Black Africans as retribution and justice. ${ }^{68}$ This argumentation made it possible for the European colonial establishment in the Americas to maintain a regime in which the roles of master and slave were factually distributed according to skin colour. ${ }^{69}$ At the beginning of the period of colonial conquests, around 1850, racial conceptions were thus already deeply entrenched in European perspectives. With regard to the African continent, they led mediated through the above-mentioned life experiences of African individuals in Europe - to counter-formulations from the African side, which were then conveyed back to local movements.

However, while racial conflict is mostly discussed regarding the relations between African populations (Black) and European merchants and colonisers (White), it has to be pointed out that the phenomenon appears in the African continent in a number of very diverse circumstances. These are equally as important as the role of the pan-African argument. As I have indicated for parts of West Africa, another typical sphere of 'racial' conflicts is that between 'Arabs' and 'Black Africans' in the Southern Sahel Zone: in those regions, 'Arab' or 'Moorish' raiders, landlords, and traders introduced Black Africans for trade into slave networks leading to North Africa and, less frequently, to the Middle East. ${ }^{70}$ The legacy of the related conflicts can still be felt in what is today described in the media as a 'racial border', running through the contemporary

67 A useful starting point is Forster, Robert, 'Three Slaveholders in the Antilles: SaintDomingue, Martinique and Jamaica', Journal of Caribbean History 36(1), 2002, 1-32, 4-7.

68 One example is Jordan, Winthrop D., White over black: American attitudes toward the Negro, 1550-1812 (fifth edition, Chapel Hill: University of South Carolina Press, 1979).

69 Drescher, Seymour, 'White Atlantic? The Choice for African Slave Labor in the Plantation Americas', in David Eltis, Frank D. Lewis, and Kenneth L. Sokoloff (eds.), Slavery in the Development of the Americas (Cambridge etc.: Cambridge University Press, 2004), 31-69.

70 Clarence-Smith, William Gervase, Islam and the Abolition of Slavery (New York - Oxford: Oxford University Press, 2006), 70-2. 
state of Mauritania eastward through Mali, Niger, and, with a particular impact, Chad and Sudan. In Mauritania, the 'Moorish' majority periodically treats 'Black' Mauritanians as 'foreigners' and as 'Senegalese', although these populations have settled for a period of many centuries - at the very least - north of the Senegal River. Questions of social status, relating to the fact that 'Black Africans' frequently have slave ancestors, have kept this situation in a problematic imbalance: indeed, in the post-colonial 'Islamic Republic', political alliances between 'Black' and 'White' Mauritanians, while frequently existent, appear to be far less stable than those created on either side of the colour line. ${ }^{71}$

The role of pan-African mobilisation is, however, far stronger when confronted with non-European immigrant groups in the territories south of the Sahara. For West Africa, Lebanese immigration is a phenomenon that led to a 'racially' defined antagonism. The three regions discussed in the case studies are principal territories of Lebanese immigration. These immigrant families had very different backgrounds in relation to their regions of origin: they were from both Christian (mainly Maronite) and Shiite or Sunni Muslim backgrounds, and village networks from Lebanon played a decisive role in this immigration. Lebanese traders subsequently enjoyed considerable success in local retail trade in West African territories. ${ }^{72}$

It has to be said that, as far as historians have been able to judge, Lebanese merchants have been an important factor within the colonial economies emerging in West Africa since the late nineteenth century. The Lebanese only partly pushed other, Black African contenders out of the retail market. In many cases, such a market had never really existed, at least not in any larger form. Lebanese merchants and their families simply occupied an obvious niche in local trade networks, which had been left unfilled by African traders. ${ }^{73}$ In rural Senegal, for instance, those merchants are remembered as a rather beneficial force: interviewees have a tendency to claim that with Lebanese participation in the local retail trade (which at present has largely disappeared in rural areas), the access to vital goods had been far easier than is the case nowadays. ${ }^{74}$

71 McDougall, E. Ann, 'Setting the Story Straight: Louis Hunkanrin and "Un Forfait Colonial”, History in Africa 16, 1989, 285-310, 285-6.

72 Winder, Bayly, 'The Lebanese in West Africa', Comparative Studies in Society and History 4(3), 1962, 296-333, 301, 305.

73 Falola, Toyin, 'The Lebanese in Colonial West Africa', in J.F. Ade Ajayi and J.D.Y. Peel (eds.), People and Empires in African History: Essays in Memory of Michael Crowder (London New York: Longman, 1992), 121-41.

74 Centre des Archives Diplomatiques de Nantes, France (CADN), Fonds 'Anciennes Colonies', Fonds Dakar, 197, Lami, French Governor of Senegal, Territoire du Sénégal - Cercle de Thiès: Rapport Politique 1950 (without number), 20 March 1951, 18. 
Nevertheless, the Lebanese were the victims of recurrent riots in most West African countries. This was in particular the case for urban communities with a certain degree of prosperity. ${ }^{75}$ As I will discuss below concerning the question of 'nationality', economic crises in the years of the First World War and the 1930s, growing infrastructural engagement of the colonial powers from 1945, and perceived injustice in the acquisition of wealth by Lebanese businessmen all provoked violent encounters between these merchants and local street mobs. Such tensions also led to the formation of associations and parties that had a clear anti-Lebanese programme. Frequently, the colonial powers indirectly allowed for such tensions and for the subsequent violent clashes. Even if European officials sympathised with the Lebanese settlers and understood their difficult position, they would normally not intervene against rioters, or would only intervene very slowly. As the British administrators of the Sierra Leonean Port Loko District argued, it was sometimes rather difficult to take sides in conflicts between 'raw natives with the most elementary ideas' and 'vile Syrians. ${ }^{76}$

The example of Lebanese immigration shows that 'racial' tensions were indeed not only limited to racism of the colonisers towards the colonised populations. The existence of those different 'racial' lines of conflict does, however, not mean that the creation of difference through colour is in any way inevitable. Hostilities between Black and non-Black inhabitants of sub-Saharan Africa were typical for the colonial period and probably widespread before, but the 'racial' frontier was far from being impenetrable: aspects of phenotype were never deterministic in creating regional hostilities, and they did not constitute an effective barrier for individuals.

I already referred to Fredrik Barth's assumption that groups define themselves mainly through designation and constant redefinition of the frontier separating them from other local communities. Gunnar Haaland has found evidence of that phenomenon for Darfur, in Sudan: the agricultural 'Black' Fur of the region could, at least for many decades until the early post-colonial phase, rather easily become integrated into the group of the nomadic 'Arab' Baggara. In those processes of shifts between identity groups, skin colour did not obviously impede the change from one community to the other. It is plausible that such

75 Kaniki, Martin H.Y., 'Attitudes and Reactions towards the Lebanese in Sierra Leone during the Colonial Period', Canadian Journal of African Studies 7(1), 1973, 97-113, 101-3.

76 The National Archives, Public Record Office, Kew, London, United Kingdom (TNA, PRo), CO/267/595, District Administrator of Port Loko District, Annual Report 1921: Port Lokko District, Northern Province (without number), without date, 2. 
phenomena of blurred 'racial' boundaries are typical for many 'racial border regions. ${ }^{77}$

Evidently, 'racial' solidarity as a category is far more difficult to create than is ethnic sentiment, for the simple reason that it needs to rely on the perception of physical otherness. Except in cases where ethnic hostilities were deliberately linked to elaborate stories of physical distinction, these 'racial' issues were thus not complementary to ideas of difference through ethnic solidarity. On the contrary, 'racial' images could help to extinguish temporarily the impact of ethnic or other community conflicts, by giving a platform of unity. ${ }^{78}$ In the African case, such 'unity' could be directed both on a pan-African ideological basis against the 'White' colonisers, or, far more often indeed, against third parties, such as Lebanese immigrants in West Africa. Like 'race', other overarching concepts also surged and were set against ethnic distinction; this is the case of the idea of 'nation' that became popular in the colonial world from the interwar period, and in sub-Saharan Africa after 1945.

\section{The Problem of Nation}

Like ethnicity, the group identification described as 'nation' refers to a sentiment that transgresses communal and regional frontiers. ${ }^{79}$ Having been formulated as a socio-political concept in Europe and European settler colonies in the Americas, the 'nation' is an 'imagined community' that involves, like ethnic groups, a common tradition, language (in most cases), and common cultural aspects. ${ }^{80}$ Indeed, some scholars do not distinguish between the two concepts: they rightly point to the fact that a distinction is frequently artificial,

77 Haaland, Gunnar, 'Economic Determinants in Ethnic Processes', in Fredrik Barth (ed.), Ethnic Groups and Boundaries: the social organization of cultural difference (Bergen: Univ. Forl, 1969), 58-73, passim; see also Cooper, Frederick, From Slaves to Squatters: Plantation Labor and Agriculture in Zanzibar and Coastal Kenya, 1890-1925 (New Haven - London: Yale University Press, 1980), 163.

78 Falola, Toyin, and Kwame Essien, 'Introduction', in Toyin Falola and Kwame Essien (eds.), Pan-Africanism, and the politics of African citizenship and identity (New York: Routledge, 2014), 1-10.

79 The 'classical text' on the nation as 'imagined community' continues to be Anderson, Benedict, Imagined Communities: Reflections on the Origin and Spread of Nationalism (London: Verso, 1991), 83-111.

8o Interestingly, in the debate about emerging concepts of 'nation', scholars also distinguish between 'primordialists' and 'modernists', see Smith, Anthony David, The Ethnic Origins of Nations (Oxford - New York: Blackwell, 1986), 7-13. 
and they follow in a way the terminology employed by early European travellers. The latter had classified the populations they encountered 'overseas' (including in sub-Saharan Africa) as 'nations', without, however, insinuating the same idea of community that the concept of 'nation' would describe in the nineteenth century. ${ }^{81}$ By contrast, other scholars see an incompatibility between the concepts of 'nation' and 'ethnic group', and hold that the appearance of ethnic solidarity in a given country normally challenges the cohesion of the 'nation', through 'tribalist' political activities or autonomous cultural manifestations. ${ }^{82}$

For Africa, the case becomes still more complicated because the concept of 'nation' arrived later than in Europe, in the Americas, and in East Asia - and it is important for the global historian in particular to compare these trajectories. It was an imported concept taken from the European colonisers, and employed and redefined by a new African elite educated in colonial and metropolitan institutions. ${ }^{83}$ These 'educated natives', 'évolués', or 'assimilados', as they were called in the different colonial terminologies, rapidly pointed to the tensions between 'national' goals and ethnic solidarities. ${ }^{84}$ Thus, most aggressively in the late colonial period and in the first years after decolonisation, Africa's political elite coming to power juxtaposed the 'modern' concept of the 'nation' with the 'ancient' and 'irrational' notions of ethnicity. ${ }^{85}$ The constant attacks of African statesmen against 'tribalism' - frequently contradicted by the hidden patronage networks favouring the respective ethnic constituencies of the several national leaders - made it difficult to discuss in a more neutral way the distinction between ethnic and national solidarity. ${ }^{86}$

81 Brass, Paul R., Ethnicity and Nationalism: Theory and Comparison (New Delhi - Newbury Park - London: Sage Publications, 1991), 62-3.

82 See, also: Wherry, Frederick F., 'The nation-state, identity management, and indigenous crafts: Constructing markets and opportunities in Northwest Costa Rica, Ethnic and Racial Studies 29(1), 2006, 124-52, 145-6.

83 Rotberg, Robert I., 'African Nationalism: Concept or Confusion?', Journal of Modern African Studies 4(1), 1966, 33-46, 39-40, 46.

84 Davis, Thomas J., and Azubike Kalu-Nwiwu, 'Education, Ethnicity and National Integration in the History of Nigeria: Continuing Problems of Africa's Colonial Legacy', Journal of Negro History 86(1), 2001, 1-11, 6.

85 Emerson, Rupert, "The Problem of Identity, Selfhood, and Image in the New Nations: The Situation in Africa', Comparative Politics 1(3), 1969, 297-312, 299.

86 Kymlicka, Will, 'Nation-Building \& Minority Rights: Comparing Africa \& the West', in Bruce Berman, Dickson Eyoh, and Will Kymlicka (eds.), Ethnicity and Democracy in Africa (Oxford: James Currey - Athens/o H: Ohio University Press, 2004), 54-71, 64-5. 
Obviously, we cannot make a distinction between 'nations' and larger 'ethnic groups' that would cover all cases to a sufficient degree. ${ }^{87} \mathrm{~A}$ key difference between the two concepts can be found in the relation of group identification to territory, and in the insistence of 'nationalists' that they be governed by unitary political institutions. ${ }^{88}$ The emergence of the concept of 'nation' as a historical process during the nineteenth century is a filling out of geographical space. In many cases, imagined or already existing practical borders had to be filled by a nascent national community. ${ }^{89}$ For ethnic solidarity, this relationship is far less evident: the link of ethnicity to tradition highlights the role of important or even sacred places, but the idea of control over a geographical territory is far less prominent.

Another of the criteria of distinction between the categories might be found in the distinct role of culture, as defined for 'national communities' by Ernest Gellner. He held that the concept of 'nation' includes a deterministic belief in the superiority of the national community's culture, imagining a future situation of 'national control' of this culture over a certain territorial space. ${ }^{90}$ By contrast, the concept of 'ethnic group' is more strongly referring to the past, and to past group 'rights', either inherited or 'spear-won'. Another tendency to define 'national sentiment' as distinct from 'ethnic solidarity' refers to the extension of the programme: according to this view, only communities of a larger size could develop a national perspective. Again, however, it seems that such terminology is unlikely to be applied for African groups. These reflections bring us back to the role of borders in the African continent. ${ }^{91}$

As I have mentioned above, 'nation' as a concept has importance for West Africans in the post-colonial period. ${ }^{92}$ From the transitions of power, African government leaders have more or less energetically attempted to forge the different groups of inhabitants in the respective territories into national communities. This project was declared a major goal of African parties by the late colonial states of the 1950s, but, in the long-term perspective, 'nations' as imagined communities rarely emerged in the African continent. It belongs to the wisdom of political scientists analysing African politics that the instability of

87 Poutignat and Streiff-Fenart, Théories, 46-7.

88 Hobsbawm, 'Ethnicity', 4.

89 Balibar, Etienne, 'The Nation Form: History and Ideology', in Etienne Balibar and Immanuel Wallerstein (eds.), Race, Nation, Class: Ambiguous Identities (London - New York: Verso, 1991, translation of orig. Paris: La Découverte, 1988), 86-106, 96-100.

90 Gellner, Ernest, Nations and Nationalism (London: Blackwell, 1983), 55-8.

$91 \quad$ Poutignat and Streiff-Fenart, Théories, $5^{2-3}$.

92 Fage, J.D., 'Continuity and Change in the Writing of West African History', African Affairs 70(280), 1971, 236-51, 243-4. 
post-colonial states can partly be attributed to this lack of support for national projects, which appears to be an essential problem in many African societies after independence.

It is easy to understand that, when it comes to the question of institutions, the very nature of African post-colonial states is highly unfavourable to stimulating such national loyalty. State structures in post-colonial sub-Saharan Africa are frequently weak. Those structures were transferred without much preparation from a model of control introduced by the European rulers, and they have proven to be largely inadequate to guarantee the protection and a rudimentary well-being of the inhabitants of many of the countries in question. In the 'normal' pattern of evolutions of post-colonial African states - a pattern that has remained prominent from independence to the end of the twentieth century and beyond - we mainly find the particular type of state that has so masterfully been discussed by Jean-François Bayart: state structures with a core of activity around the centre of political power, and with concentric circles of patronage networks around this centre. ${ }^{93}$ Large parts of the African societies have not been covered by those structures. The representatives of the state in the more peripheral or remote regions of the countries, are frequently regarded as completely detached from local interest and local necessities, or even despised as parasites by the local inhabitants. ${ }^{94}$ Access to resources has been uneven in such structures: only those populations enjoying a regular presence in the capital or in key areas of the country as defined by the ruling elites, or those belonging to patronage networks through influential intermediaries, have been able to participate in the exercise of and the struggle for political power.

This weakness of post-colonial African state structures can be illustrated through an analysis of the particular situations of political crisis that were already common in the decade after the transitions of power. Whenever the governments of the post-colonial states were challenged, this challenge rarely concerned groups outside of the core community and the key regions. Not surprisingly, the first coups d'état in sub-Saharan Africa after decolonisation, in the 196os, left the countryside rather untouched. ${ }^{95}$ After a phase of initial destabilisation and violent protest in the capital, army leaders profited from the occasions and exploited the 'national' crisis to usurp political power.

\footnotetext{
93 Bayart, Etat, 281-308.

94 Wunsch, James S., 'Refounding the African State and Local Self-Governance: The Neglected Foundation', Journal of Modern African Studies 38(3), 2000, 487-509, 498.

95 Nkendirim, Bernard A., 'Reflections on Political Conflict, Rebellion, and Revolution in Africa', Journal of Modern African Studies 15(1), 1977, 75-90, 79.
} 
Starting in Congo-Brazzaville in 1963 , this same pattern was repeated several times over. Dahomey (present-day Benin) in 1963 or Upper Volta (present-day Burkina Faso) in January 1966 are two more examples of urban protests led by trade union militants that gave the national army the excuse to topple the elected presidents. It has to be emphasised that in all those cases, ethnic sentiment, if it was at all mentioned, played a minor role. On the contrary, the logics of the nation-state as they had been defined by the nationalist discourse, and the lack of a power base for the dominant elites, permitted the military to claim political leadership in the respective states. This process started nearly always at the centre of the state structure, in the capital and its urban agglomeration.

The weak links between the urban centres and their agglomerations as cores of political power and the 'countryside' have been very powerful obstacles, which ultimately disallowed a leading function for 'national' feelings in the identification repertoires of African groups and individuals. In Europe, in the United States, and in the former British Dominions (and in parts of Latin America that had long been dominated by European settlers converted into a Creole elite) conditions were different: here, the process of nation-building started in the late eighteenth and the early nineteenth century, and it consequently had a longer-lasting impact on local solidarities. Notably, and perhaps more importantly, in the respective cases, such creation of widely important national sentiment went hand in hand with a forceful penetration of the countryside by political structures.

It is true that in the different geographical areas of the above-mentioned larger zones of Europe, former European settler colonies, and Latin America, nationalist fervour was, in part and mostly in the beginning, an elite sentiment. However, in the course of the nineteenth century, in most cases, it began to have a strong effect on the rural zones and became, to a certain degree, a mass phenomenon. Broader access to an education system that was increasingly unified and controlled from above; army conscription; mass elections, and a considerable use of sites of memory and cultural manifestations were behind the widespread dissemination of nationalist ideas. Due to the limitations inherent in the colonial systems, all these phenomena are partly or completely absent from the political scenery of colonies. However, for the African territories before 1960 this effect was strongest for the large majority of populations that lived far away from the administrative capitals. ${ }^{96}$ While the colonial powers commemorated their respective empires as part of their own 'national agenda', and celebrated the deeds of the 'heroes' of the colonial period; while

96 Young, Crawford, The Politics of Cultural Pluralism (Madison: University of Wisconsin Press, 1976), 65-77. 
the colonial administrations sometimes turned to the commemoration of fraternity between Africans and Europeans (referring, for example, to the African contribution during the World Wars, which was immense in the case of the French war effort), they were not inclined to give room to any 'national' feeling that could be turned against the metropole. ${ }^{97}$

However, even after independence and in the first two decades after decolonisation, larger efforts to create such national sentiment inside the African states remained relatively rare. While most African statesmen continued to pay lip service to 'the nation', we do not find much concrete engagement to foster feelings of national unity. In the field of the (physical) sites of memory, there were some occasional efforts to stimulate the growth of national sentiment. Nevertheless, it is occasionally difficult to decide if a 'national monument', such as the costly arc de triomphe of Banjul (erected after the 22 August 1994 coup d'état), in the Gambia, was really constructed as an embodiment of an imagined nation's glory, or for the apotheosis of a particular leader. ${ }^{98}$

Moreover, in the case of the African states, an additional problem for the distribution of the concept of the nation-state is posed by the rather banal fact that the physical borders of colonial territories, which became independent countries, had naturally been set by external forces. As has been discussed over decades, colonial borders have, in a huge majority of cases, no connection whatsoever to boundaries of pre-colonial states or groups as they existed before $1850 .{ }^{99}$ Not surprisingly, the 'primordialists' amongst historians and anthropologists claim that colonial borders create, as a matter of fact, serious problems. According to the 'primordialist' position, these

97 Michel, Marc, “Mémoire officielle", discours et pratique coloniale: le 14 juillet et le 11 novembre au Sénégal entre les deux guerres', Revue Française d'Histoire d'Outre-Mer $77(287)$, 1990, 145-58; on the lack of 'African' sites of memory, see also Fall-Sokhna, Rokhaya, and Abdoulaye Touré, 'Les lieux de mémoire: des sources historiques encore peu exploitées au Sénégal', in Ibrahima Thioub (ed.), Patrimoine et sources historiques en Afrique (Dakar: Université Cheikh Anta Diop de Dakar - Union académique internationale, 2007), 105-11, 108-10.

98 Wiseman, John A., 'Letting Yahya Jammeh off Lightly', Review of African Political Economy 72, 1997, 265-76; Mbodj, Mohamed, 'L'invention d'une tradition: anciens sites et nouvelle mémoire ou les ambiguïtés de la célébration de l'indépendance de la Gambie en 1965', in Odile Goerg (ed.), Fêtes urbaines en Afrique: espaces, identités et pouvoirs (Paris: Karthala, 1999), 229-54, 243-9.

99 Deveneaux, Gustav K., 'The Frontier in Recent African History', International Journal of African Historical Studies 11(1), 1978, 63-85, 74-5. 
borders cut the communication between members of the same 'tribe', or ethnic group. ${ }^{100}$

Given the existence of those 'artificial borders', the evolution of selfperceived nations in the sense of the nineteenth century, as was typical for the European experience, is quite distant for some regions in their post-colonial phase, but especially for the African realities after independence. Where African leaders appeal to the 'nation' as a principle of unity, they transpose an artificial concept, which is questionable in its appropriateness for the particular, historically-grown situations in the African continent. At best, from this point of view, such an appeal might be a weak call to mobilise a certain number of individuals, just like a slogan coming from a charismatic leader. However, it is highly unlikely to make the same individuals respond to it in a sustained emotional way. Such an interpretation would mean that 'nation' as a concept cannot really become an element of reference in the identification repertoire of an African individual. ${ }^{101}$

These prognostics about a possible role for 'the nation' in the African context seem to follow a clear, historically-grounded logic in a global comparison. However, as with other group categories, the reality on the ground is not as schematic. In the following pages, I will demonstrate this through a number of incongruities between the classical perspective that insists on the inadequacy of the conception of 'nation' for sub-Saharan Africa, and some empirical findings in a global history perspective which at least cast doubt on this vision.

First of all, boundaries in the sense of borders between 'nations,' may have been artificial constructs, but they have nonetheless been filled with an emotional meaning. This becomes obvious from the agency of the African residents in the redefinition of certain border regions, which has been pointed out in many innovative ways by Paul Nugent. Although the boundaries in themselves had been negotiated by representatives of the European colonial powers, and although these borders frequently cut through language groups and ethnic communities, they became in many cases themselves a vivid and

100 Davidson, Basil, The Black Man's Burden: Africa and the Curse of the Nation-State (London: James Currey - Harare: Baobab Books - Nairobi: E.A.E.P. - Kampala: Fountain Publishers, 1992), 224-42; Fanso, Verkijika G., 'Traditional and colonial African boundaries: concepts and functions in inter-group relations', Présence Africaine 137-40, 1986, 58-75. See an early challenge in Zartman, I. William, 'The Politics of Boundaries in North and West Africa', Journal of Modern African Studies 3(2), 1965, 155-73, 160.

101 For 'dual citizenship' in Kenya, with reference to both the nation and the ethnic groups, see Ndegwa, Stephen N., 'Citizenship and Ethnicity: An Examination of Two Transition Moments in Kenyan Politics', American Political Science Review 91(3), 1997, 599-616, 613. 
advantageous part of the local reality. ${ }^{102}$ Even as a European concept, which had only scarcely been remodelled by African leaders for their own purposes, the separation of two 'nations' by a physical border could develop its own dynamics.

Obviously, the experience of national borders in sub-Saharan Africa is far less related to military conflict and to objectives of territorial control than elsewhere. ${ }^{103}$ The latter motives had been common in nineteenth- and early twentieth-century Europe, with tensions and military clashes being frequently linked to a perceived necessity of 'national expansion'. This being said, and while West African governments have mostly respected the territorial integrity of neighbouring countries, it would be an exaggeration to claim that conflicts between governments of neighbouring African post-colonial states have never been related to questions of the national border. ${ }^{104}$ At least within nationalist arguments and in attempts for mobilisation, reference has abundantly been made to the suspected aggressive goals of neighbouring national governments. An instructive case for this problem, particularly for the 196os, is the example of Ghana and Togo.

After national independence of both West African states, the Ghana-Togo border has been a constant source of friction. These tensions have a long prehistory. Togo had had its first colonial border with the then-British colony of the Gold Coast during its period under German rule; until 1914, this German colony included regions further to the west and covered parts of the currentday Ghanaian Volta Region. On those (colonial) grounds, the first independent Togolese governments formulated territorial claims towards an entire region governed by the neighbouring country. By contrast, the Ghanaian governments in Accra insisted on their rights for control over large parts or even the whole of the independent Togolese territory. They argued that in 1960 a majority of the 'Togolese people' had been robbed of their desired opportunity to unite with the Ghanaian state. ${ }^{105}$ Both claims are nowadays largely, if not always, detached from any ethnic perspective, although they are not ignorant of the

102 Nugent, Paul, 'Arbitrary lines and people's minds: a dissenting view on colonial boundaries in West Africa', in Paul Nugent and A.I. Asiwaju (eds.), African Boundaries: Barriers, Conduits and Opportunities (London - New York: Frances Pinter, 1996), 35-67, 41-6.

103 Kacowicz, Arie M., "Negative” International Peace and Domestic Conflicts, West Africa, 1957-96', Journal of Modern African Studies 35(3), 1997, 367-85, 382.

104 Kornprobst, Markus, 'The Management of Border Disputes in African Regional SubSystems: Comparing West Africa and the Horn of Africa',Journal of Modern African Studies 40(3), 2002, 369-93, 388.

105 Austin, Dennis, 'The Uncertain Frontier: Ghana-Togo', Journal of Modern African Studies 1(2), 139-45, 142; and Bening, R. Bagulo, 'The Ghana-Togo Boundary, 1914-1982', Africa 
fact that border-crossing communities have continued to have an existence in both states. The example of the Ghana-Togo border shows that, for a period of some decades, even violent conflicts were an imaginable outcome during border tensions between two post-colonial African states. In this case as in others in sub-Saharan Africa, the governments of both states formulated their claims with clear reference to national territorial demands and necessities. Therefore, the employment of national demands as justification for aggressive state behaviour is, in principle, an option in sub-Saharan Africa as it was in other parts of the post-colonial world. However, claims for nation-building often remained as a concept in the drawer, and have in any way been less prominent than in Europe and other parts of the globe.

Obviously, border conflicts are not the only way in which a 'national' perspective has played a role for individuals and groups in sub-Saharan Africa, in particular for the period after independence, but sometimes even before. As in Europe, particularly in the case of post-First World War Eastern Europe, the term 'nation' could be employed to construct a concept of a regional community, but in a sense that clearly was to exclude certain 'minority groups'. In comparable ways to settings of conflict between groups distinguished as different on 'ethnic' terms, such distinctions between we-groups and outsiders were sometimes based on mainly emotional behaviour. As the concept of 'nation' is, however, a particularly young category in the case of the African continent, the exclusion of individuals from the national community can mostly be interpreted as a step to change and polarise the balance in a country's resource distribution.

In these scenarios, out-groups are usually accused not only of belonging to another ethnic group, but also of holding their allegiance to another nation (and, if these distinctions are made, to the government of another state). In many cases, this argumentation is overtly connected to questions of ethnicity. ${ }^{106}$ The 'nation' is, in such circumstances, formulated as a frontier against an internal enemy, as David Cappell has expressed it for Côte d'Ivoire as an African example. The situation in that country between 2002 and 2011 is very probably the most illustrative recent West African example for inclusion and exclusion under concepts formulated as 'national', and for its overlaps with ethnic claims. ${ }^{107}$ The conflict appears at first glance as one between northern and

Spectrum 18(2), 1983, 191-209. The turbulent relations of Ghana and Togo will reappear in chapter 5 .

106 Smith, Origins, 154-7.

107 Cappell, David A., 'The Nation as Frontier: Ethnicity and Clientelism in Ivorian History', International Journal of African Historical Studies 22(4), 1989, 671-96. 
southern alliances of ethnic groups, combined with a religious antagonism between Muslims and non-Muslims. ${ }^{108}$ However, this simplified picture corresponds more to rhetoric and less to long-standing allegiances. With increasing force during the 1990s, Ivorian governments, and leading politicians in the electoral context, had employed a discussion of different variants of a national community, to mobilise the involved groups. During the years of civil war, this national argument was formulated by both sides. Côte d'Ivoire therefore constitutes an excellent example of how these mechanisms work, in the African continent and beyond.

The growing national dimension of conflict in Côte d'Ivoire was, however, particularly the work of President Laurent Gbagbo and his Front Populaire Ivoirien (FPI) government in power in Abidjan until 2011. The propaganda of the FPI based itself on the question of the ivoirite (the Ivorian identity) of any resident, as a principle of adherence to the Ivorian nation. ${ }^{109}$ It was formulated in sufficiently vague terms, in order to be enlarged when necessary, so as to include allies of the government. After 2000, this principle was crucial in decision-making processes, as it allowed integrating individuals in or excluding them from the in-group of citizens. The northern rebel groups were of heterogeneous composition, but could thus be lumped together as an external threat. ${ }^{110}$ They were often characterised as 'Mossi foreigners' (Mosi being the main language group in the northern neighbouring country), as 'Burkinabè', and, consequently, as intruders from Burkina Faso paid by the government of the neighbouring state. This strategy did not always work. However, more often than not, inhabitants of southern Côte d'Ivoire proved to be sensitive to those arguments, and their impact might explain in part the resilience of the troops supporting the Gbagbo government. ${ }^{111}$

108 Vidal, Claudine, 'La brutalisation du champ politique ivoirien 1990-2003', in Jean-Bernard Ouédraogo and Ebrima Sall (eds.), Frontières de la citoyenneté et violence politique en Côte d'Ivoire (Dakar: CODESRIA, 2008), 169-81, 174-6.

109 Zoro, Epiphane, “Je suis un Sidibé de Tiémélékro". L'acquisition de la nationalité ivoirienne à titre originaire: critère juridique ou critère anthropologique?', in Jean-Bernard Ouédraogo and Ebrima Sall (eds.), Frontières de la citoyenneté et violence politique en Côte d'Ivoire (Dakar: CODESRIA, 2008), 79-87, 84-6; Arnaut, Karel, 'Mouvement patriotique et construction de "l'autochtone" en Côte d'Ivoire', Africa Development 33(3), 2008, 1-20, 8-10.

110 A polemic view is given in Blé Kessé, Adolphe, La Côte d'Ivoire en guerre: le sens de l'imposture française (Paris: Harmattan, 2005).

111 Colin, Jean-Philippe, Georges Kouamé, and Débégnoun Soro, 'Outside the autochthonmigrant configuration: access to land, land conflicts and inter-ethnic relationships in a former pioneer area of lower Côte d'Ivoire', Journal of Modern African Studies 45(1), 2007, 
This type of conflict, in which the limits between ethnically defined violence and a struggle for inclusion into or exclusion from 'the nation' are blurred, appears to have become typical throughout the whole of sub-Saharan Africa, at least from the 199os. In East Africa, the logics of the group conflict in Kenya in 2007/08 have some striking similarities with the civil war in Côte d'Ivoire. ${ }^{112}$ Coming briefly back to the region of Central Africa, it can be argued that a similar strategy of exclusion was for a long time successfully employed in Congo-Kinshasa, during the late years of the decades-long reign of authoritarian President Joseph-Désiré Mobutu. The Banyamulenge, a numerous, Tutsispeaking group in the east of the country, were labelled 'Rwandans' by the Congolese government, thus excluding them symbolically from the 'nation' and portraying them as tools of a genuinely 'foreign' movement. Again after 1998, this stigmatisation through a 'national' argumentation made the Banyamulenge 'foreigners' fair game for plunderers from other groups in eastern Congo. Ironically, these attacks made the Banyamulenge actively seek contact with the Rwandan government, in order to obtain protection, and the group's 'Rwandan-ness' therefore became a self-fulfilling prophecy. It did not follow any determined paths, but it became true through the permanent violence against a group having been a part of the range of communities living in Congo-Kinshasa, which after its exclusion from the Congolese 'nation' needed a protector from outside in order to survive. ${ }^{113}$

In the three African cases mentioned, as in others, important material resources were at stake. Under their attraction, the reference to 'the nation' allowed local groups to claim the rights of locals ousting foreigners from the unauthorised use of such 'national' resources. This mechanism of designating

33-59, 49-53; Babo, Alfred, L'étranger' en Côte d'Ivoire: crises et controverses autour d'une catégorie sociale (Paris: Harmattan, 2013).

112 Odhiambo, E.S. Atieno, 'Hegemonic Enterprises \& Instrumentalities of Survival: Ethnicity \& Democracy in Kenya', in Bruce Berman, Dickson Eyoh, and Will Kymlicka (eds.), Ethnicity and Democracy in Africa (Oxford: James Currey - Athens/он: Ohio University Press, 2004), 167-99, 173-4; Muigai, Githu, 'Jomo Kenyatta \& the Rise of the EthnoNationalist State in Kenya', in ibid., 200-17, 211-2. On the evolution of 2007/08 postelectoral violence, see Anderson, David, and Emma Lochery, 'Violence and Exodus in Kenya's Rift Valley, 2008: Predictable and Preventable?', Journal of Eastern African Studies 2(2), 2008, 328-43; and Bratton, Michael, and Mwangi S. Kimenyi, 'Voting in Kenya: Putting Ethnicity in Perspective', Journal of Eastern African Studies 2(2), 2008, 272-89.

113 Vlassenroot, Koen, 'Citizenship, Identity Formation \& Conflict in South Kivu: The Case of the Banyamulenge', Review of African Political Economy 29(93-4), 2002, 499-515; Willaume, Jean-Claude, Banyarwanda et Banyamulenge: Violences ethniques et gestion de l'identitaire au Kivu (Brussels: CEDAF, 1997), 83-99. 
certain groups as 'non-nationals' and, consequently, as out-groups, appears in many places. Quite visibly, these measures were even easier to employ if the attacked group was an overseas immigrant group, where so-called 'racial' factors as discussed above could be brought into the discussion. I have already pointed to the Lebanese in West Africa as targets in such processes, and the Indians and other Asians in South and East Africa constitute a second large immigrant group in the African continent.114 The experiences of these different communities are important here because they represent the earliest targets of the employment of arguments that we could describe as 'national', or 'proto-national' - the latter term is appropriate if we want to point out that they started to be used long before national independence.

The Lebanese communities of West African territories and countries, such as Senegal, the Gambia, Guinea-Conakry, Sierra Leone, or Ghana, were from 1900 and over many decades the victims of 'racial' riots initiated by local African inhabitants. These riots had begun to occur well before the end of colonial rule: they had a certain long-standing tradition and notoriety. ${ }^{115}$ The representatives of the colonial state occasionally contributed to those hostilities, particularly if they favoured principles of colonisation that tended to 'protect' African societies from obnoxious 'foreign' influences. However, if colonial administrators encouraged African militants to attack Lebanese settlers, this was mainly so through their passiveness in policing activities. There is little doubt that it was usually local African groups themselves who took the initiative against the 'foreigners'.

In 1919, African inhabitants of the city of Freetown in Sierra Leone destroyed the stores of 'Syrian' merchants established there for some decades already. What appeared to be a spontaneous riot was probably a pre-organised action, and quite representative of the negative opinion the locals had developed towards the immigrants. ${ }^{116}$ Similar disturbances would reappear again and again, in different West African territories, under different colonial rulers. In the 1940s and 1950s, the protracted anti-Lebanese sentiment in large parts of the African (urban) populations could even be manipulated by European settler leaders - a marginal community in the West African context - who

\footnotetext{
114 Ogutu, Matthias A., 'Commercial Specialisation and Adaptation of Ethnic Groups',Journal of Modern African Studies 11(3), 1973, 465-9.

115 Arsan, Andrew, Interlopers of empire: the Lebanese diaspora in colonial French West Africa (New York: Oxford University Press, 2014).

116 Abdullah, Ibrahim, 'Rethinking the Freetown Crowd: The Moral Economy of the 1919 Strikes and Riot in Sierra Leone', Canadian Journal of African Studies 28(2), 1994, 197-218, 208-9.
} 
wanted to hide their own racist positions about Africans behind a common front against Lebanese merchants. ${ }^{117}$

Under colonial conditions, the arguments employed by rioters against such 'Asian' immigrant groups were a mixture between 'racial' and territorially defined claims. According to this logic, the Lebanese were regarded as excluded from a community that can best be described as 'proto-national'. This does not mean that during the violence against Lebanese inhabitants of Dakar or Freetown the rioters would clearly define themselves as 'Senegalese' or 'Sierra Leoneans'; mostly, this feeling of community spirit against 'foreign' groups was only defined through the criteria of exclusion. Nevertheless, it is remarkable that the motions of hatred that mobilised the urban African groups against foreigners excluded from the 'proto-nation' were, in many cases, highly effective. ${ }^{118}$

Hostile positions of the African inhabitants of different West African regions towards Lebanese settlers continued after national independence, and have frequently entered the national institutions. ${ }^{119}$ Individuals from Lebanese families have now been living on African soil for generations, but their generally negative image has been well preserved into the post-colonial period. ${ }^{120} \mathrm{In}$ the last five decades, the legacy of the anti-Lebanese hostilities has had an impact on the legislative process in a number of countries, as many national governments have introduced laws tending toward the gradual exclusion of the Lebanese from citizenship and the related rights. These measures were ultimately identifiable as concessions to frustrated supporters of the governments; the Lebanese seemed to be a suitable scapegoat for the failure of 'the nation's' economic and social efforts.

For our understanding of 'nation' as juxtaposed with 'ethnicity', the argumentation in favour of those measures is as interesting as the similarities in the more general rhetoric of exclusion. Indeed, we encounter the same strategy of

117 Keese, Alexander, 'Colons français, politiciens africains et marchands libanais au Sénégal colonial', Africa (Roma) 6o(2), 2005, 201-20; Bierwirth, Chris, 'The initial establishment of the Lebanese community in Côte d'Ivoire, ca. 1925-45', International Journal of African Historical Studies 30(2), 1997, 325-48; Archives Nationales Sénégalaises, Dakar, Senegal (ANS), 11D1/162, Forget, Assistant Commissioner of Bignona, to Police Commissioner, commanding the Fourth Mobile Unit of Sûreté, Ziguinchor, Comportement des LibanoSyriens $\left(\mathrm{n}^{\circ} 73\right), 7$ November 1956, $1-3$.

118 Leighton, Neil O., 'The Lebanese in Sierra Leone', Transition 44, 1974, 23-9, 28.

119 Luke, David Fashole, and Stephen P. Riley, 'The Politics of Economic Decline in Sierra Leone', Journal of Modern African Studies 27(1), 1989, 133-41, 137-8.

120 Leichtman, Mara A., 'The legacy of transnational lives: Beyond the first generation of Lebanese in Senegal', Ethnic and Racial Studies 28(4), 2005, 663-86, 668-9. 
argumentation as in the case of the above-mentioned conflicts in Côte d'Ivoire or in Congo-Kinshasa: the main argument brought forward against the rights of citizens or residents of Lebanese origin relies on the assumption that the Lebanese adhere to a foreign 'nation'. They are said to be unlikely to show loyalty to the African state, as they are identified as clients of a Middle Eastern government. ${ }^{121}$ 'The Lebanese' are thus defined as an out-group with respect to 'the nation', in much the same way as 'unwelcome' ethnic groups in other contexts. The case of 'the Indians' in East and Southeast Africa resembles the Lebanese experience up to a point. Populations of Indian origin had quickly assumed a dominant position in many parts of the commercial sector, which they maintained over the decades of colonial domination. As 'foreigners', they became a convenient scapegoat for late colonial and post-colonial mobilisation. ${ }^{122}$ In East (and southern) Africa, the impact of the colonial heritage was very strong in those respects. In territories where the colonial rulers had favoured a kind of segregation based on skin colour, the segmentation into different 'racial' groups thus imposed long outlived, in the minds of the populations concerned, the end of colonial domination. It eventually led to the legal discrimination of 'Indian' residents. ${ }^{123}$

From these cases we can point to a number of facts concerning group identifications and the concept of 'nation' in sub-Saharan Africa, as opposed to global historical patterns. First, differences in skin colour ('racial' differences) were helpful for militants, proto-national and nationalist leaders, and politicians, to define certain groups as out-groups from the perspective of the 'nation'. This made groups of long-distance immigrants, such as Middle Eastern or South Asian groups, particularly easy targets of violence. Second, the principle of 'nation' could also be turned against particular ethnic groups by claiming that the latter were 'foreigners'. Third, conflicting territorial claims by post-colonial governments, such as in the conflict between Ghana and Togo, or a devastating civil war, such as in Côte d'Ivoire or in Eastern Congo-Kinshasa, added to the violence of such clashes. However, the different categories of conflict were not obligatory: it appears that the exclusion of the 'other' from the

121 Akyeampong, Emmanuel K., 'Race, Identity and Citizenship in Black Africa: The Case of the Lebanese in Ghana', Africa 76(3), 2006, 297-323.

122 Power, Joey, 'Race, Class, Ethnicity, and Anglo-Indian Trade Rivalry in Colonial Malawi, 1910-1945', International Journal of African Historical Studies 26(3), 1993, 575-607, 584-7; Gregory, Robert G., South Asians in East Africa: An Economic and Social History, 1890-1980 (Boulder - Oxford: Westview Press, 1993).

123 Don Nanjira, Daniel D.C., The Status of Aliens in East Africa: Asians and Europeans in Tanzania, Uganda, and Kenya (New York etc.: Praeger, 1976). 
'proto-nation' was a very useful principle even when all those above-mentioned conditions were non-existent.

In the African continent, we find an early tendency to attack individuals defined as 'nationals' (one might again be inclined to say 'proto-nationals' for the late colonial period) of a neighbouring territory under conditions when such 'foreigners' were competitors for positions and goods. A dramatic example from the late colonial period, from 1958, is the experience of Togolese and Dahomean workers living in Abidjan. During an upsurge of apparently socially motivated riots, these 'foreign' labourers became the victims of attacks and many were transported out of near-independent Côte d'Ivoire and back to their countries of origin, with the tacit consent of the then autonomous Ivorian government. ${ }^{124}$ Since the advent of national independence in Ghana, particularly at moments of internal social tensions, the same has regularly occurred with Nigerians employed as labourers on Ghanaian soil, who were expelled in several situations. ${ }^{125}$ In the latter cases, 'proto-national' or national criteria were introduced into the debate, as members of the in-group hoped to obtain resources withdrawn from the expelled 'foreigners'. Moreover, the ensuing riots allowed reaffirming alliances of different ethnic groups that could thus be built to back the newly independent governments. ${ }^{26}$ However, scholars should not underestimate the (perhaps surprisingly) emotional bond of the involved individuals to the national principles in question; there is no need to regard them as entirely instrumental. As in nineteenth- or early twentieth-century Europe, questions of national exclusion could have a great impact on the sentiment of individuals as group members and transform themselves into entrenched attitudes.

Some factors under colonial rule benefited the emergence of 'proto-national sentiment' among populations that had not known any former links between their respective communities. Thus even before the independence of the African states, such a sentiment was created through the implementation and experience of territory-wide elections. It was, obviously, the European administrations that formulated the initial rules of the game and installed new institutions according to territorial principles. However, the African elites internalised this territorial and 'proto-national' perspective of emergent mass

124 Keese, Alexander, 'Introduction', in Alexander Keese (ed.), Ethnicity and the long-term perspective: the African experience (Berne: Peter Lang, 2010), 9-29, 13.

125 Peil, Margaret, 'The Expulsion of West African Aliens', Journal of Modern African Studies 9(2), 1971, 205-29, 206, 212, 218.

126 Brydon, Lynne, 'Ghanaian Responses to the Nigerian Expulsions of 1983', African Affairs $84(337), 1985,561-85,563-4$. 
democracy. They regarded themselves as being in connection with a particular territory whenever they had to interact with the delegates of other colonial units. In the federal institutions of colonial French West Africa, for example, the 'Dahomeans' and the 'Senegalese' above all, but also the 'Ivorians', the 'Nigeriens', the 'Guineans' or the 'Soudanese' appear on the political stage as clearly distinguished, self-conscious groups (in spite of existing overlaps). Their representatives often focused on the well-being of the populations of a (proto) national territorial space. ${ }^{127}$ More than any 'tribal' solidarities, the obligations of governments to this national self-definition contradicted the panAfrican rhetoric that, on the surface, appeared to be so dominant in the public sphere in the 1950 s and 1960 .

It might be argued that, in spite of these examples, 'national' criteria of affiliation have been less important for many African individuals than they are for Europeans, Americans, or Asians. Nevertheless, those 'national' feelings began to play a role rather early in the colonial phase, and they continue to express their real presence through simple acts of affiliation. National enthusiasm on the occasion of sports events, particularly regarding football, and becoming most visible during the Africa Cups, is a significant sign of the importance of this national affiliation. In some earlier, particularly spectacular cases, such as the near football war between Gabon and Congo-Brazzaville in 1962 leading to the deportation of hundreds of 'foreigners', national sentiment produced through such events could even be transformed into political conflict between the governments of states. ${ }^{128}$

These notions of national sentiment are now sometimes, and under particular circumstances, stronger than ethnic solidarities. While we have no study so far attempting to analyse the relationship between the two categories from a long-term perspective, it can nevertheless be underlined that in some cases members of an ethnic group separated by a border, identified more with the community defined through the 'nation', than with their ethnic peers at the other side of the borderline. ${ }^{129}$ This also eclipses any identification as borderlanders' in the sense of Nugent's reflections. As in the case of the border between Benin and Nigeria, both sides hold explicitly national stereotypes of

127 Benoist, Joseph-Roger de, La balkanisation de l'Afrique Occidentale française (Dakar: Nouvelles Editions Africaines, 1979), 238-9.

128 Keese, 'Introduction', 13-4; Clignet, Rémi, and Maureen Stark, 'Modernisation and Football in Cameroun', Journal of Modern African Studies 12(3), 1974, 409-21, 416-7.

129 Miles, William F.S, and David A. Rochefort, 'Nationalism versus Ethnic Identity in subSaharan Africa', American Political Science Review 85(2), 1991, 393-403. 
the others. ${ }^{130}$ It must of course be repeated that available research on 'national' versus ethnic and regional sentiment in border areas and beyond is, for subSaharan Africa, still quite insufficient. Nevertheless, the examples mentioned give us indications that the 'national' variable can, at least sometimes, be the more important one. Thereby, many regions of the African continent join a global mainstream.

As a whole, we need to draw one major conclusion from this discussion: we have to take 'national' sentiment into account as a point of reference for African individuals. Moreover, in its 'proto-national' forms - with reference to a territory created by colonial conquest and administrative organisation - it figures far earlier in regional histories than the nationalist manifestations of the post-Second World War period, and, afterwards, the independences. We can show cases of 'proto-national' solidarity and mobilisation from the manifest establishment of colonial rule over large parts of sub-Saharan Africa around 190o. This sentiment grew through the decades of setting up a colonial administration through territorial institutions. It may be true that the conditions for the emergence of such solidarities were clearly set from outside, but Africans soon referred to those solidarities. These references included the outright reappropriation and employment of 'proto-national' and 'national' perceptions in the struggle for material resources, in which African leaders applied those criteria quite masterfully. National feelings nonetheless have remained a weaker factor in sub-Saharan Africa, as compared to other regions. This being said, they had an impact on the portfolio of identifications that African individuals have. As we have seen, this can under some circumstances even lead individuals into a type of violent action that has, in fact, nothing to do with ethnic solidarities.

\section{States and Their Rulers}

Consequently, it is correct to say that the populations (or a part of the populations) of a given territorial unit can define themselves as a 'nation' - but that this is not a necessary process. Such a perspective emphasising the merger of different populations, in which the state is a 'hybrid paterfamilias...building community out of difference' is a possible outcome of such processes - but it is not an automatic result. ${ }^{131}$ The national perspective might give particular

130 Flynn, Donna, "We are the border": identity, exchange and the state along the BéninNigeria border', American Ethnologist 24(2), 1997, 311-30, 326.

131 Alonso, 'Politics', 396. 
opportunities for an extremely emotional link between the territory and its inhabitants, as is typical in Europe or North America, and less frequent in subSaharan Africa. However, individuals could also have the option to directly identify with existing structures of political power, expressed through 'the state. ${ }^{132}$ In this case, it is not of particular interest for an individual to formulate a tradition concerning 'national' language and culture. It is amply sufficient for the individuals in question to be accustomed to interact with institutions of local power, and to address those institutions to ultimately obtain basic needs, in particular protection. Such customary behaviour will potentially lead local groups to identify in more durable ways with the political structures.

Obviously, the relations of an individual with institutions of power are not at all necessarily depersonalised. Without referring too much to the Weberian model of ideal types of organisation of power, we could clearly say that traditions of power and charismatic elements are very much part of the relations between a local group or an individual and political structures that can be described as 'state' structures. ${ }^{133}$ In many cases, the individual feels and expresses solidarity with the representative of power, such as the local ruler, while the ruler of course does not know the individual personally. 'Crown', 'state' or 'realm' are here, in their effects of binding the loyalty of the individual, to be understood in a similar function. The range between a feeling of adherence to a patria in the early modern sense of the word, which is allegiance to the power of a crown and of a ruling dynasty, and an impersonal state patriotism formulated, in particular, in post-Second World War Europe as an 'antidote' against ideological radicalisation, may be quite wide. Nonetheless, the effect of adhering to particular institutions of power, being expressed through reference to concrete persons or not, is, as a category in an individual's identification repertoire, nearly the same.

Through such a conclusion, we will also avoid engaging too deeply in the debate about the definition of 'the state', as this debate often focuses on questions of terminology, and suffers greatly from misunderstandings between different languages within the different countries of scholarship. Indeed, Anglophone researchers are frequently at odds in their terminology with colleagues from European countries. In particular, German-speaking scholars have in the past been very strict in their terminology regarding the criteria of

\footnotetext{
132 Connor, Walker, 'A Nation is a Nation, is a State, is an Ethnic Group, is a...', Ethnic and Racial Studies 1(4), 1978, 377-400, 380-2.

133 Weber, Max, Wirtschaft und Gesellschaft: Grundriss der verstehenden Soziologie (fifth edition, Tübingen: Mohr-Siebeck, 1980 [1922]), 153-4.
} 
definition of the 'state'. According to Wolfgang Reinhard's outstanding monograph on the evolution of statehood, it would be gradually allowable only from the late eighteenth century for territorial units to be addressed as states (or 'modern states'). Evolutionary criteria such as a certain degree of bureaucratisation, specialised offices, and a tax and contribution system abstracted from the person of a ruler or the tradition of a ruling dynasty, are regarded as mandatory in defining this 'modern state.' ${ }^{134}$

Anglophone historians are less strict when it comes to characterising territorial rulerships as states. For them, the decisive criterion is the existence of structures of power related to territorial control, but these structures do not need to be too formalised. 'State' in this sense is a more flexible concept. Its existence would be defined more through the results of successful control over larger population groups, than through the methods applied and through their degree of formalisation.

This second, more flexible approach allows us to discuss political units under colonial rule, including in sub-Saharan Africa, between the period before the European conquest and the end of the colonial regimes according to their degree of 'statehood', meaning the level of centralisation and effective control over populations. It is difficult to understand those results in their eventual continuity with earlier pre-colonial periods: our limitations are extreme, due to a lack of sources. Any attempt to analyse the nature of West African political entities of the pre-colonial period faces the near-irresolvable problem of distinguishing mythical from historical elements. We can be rather certain, however, that territorial entities before 1800 were in general little 'advanced' regarding a formalisation of power structures. This is not dissimilar to other parts of the globe, as in the same period in both Europe and the Ottoman Empire, and in other Muslim empires of Asia and North Africa, excessively formal institutions were also rather the exception than the rule. ${ }^{135}$ Although the level of territorial control was in many cases already far more successful than in the African continent, the government of territories remained frequently organised through a web of patronage relations, hereditary functions, and efforts to discipline the periphery.

134 Reinhard, Wolfgang, Geschichte der Staatsgewalt:Eine vergleichende Verfassungsgeschichte Europas von den Anfängen bis zur Gegenwart (second edition, Munich: C.H. Beck, 2000), $16-7$.

135 See the analysis of Christian Windler on the beylik of Tunis before the French protectorate in 1881 in Windler, Christian, La Diplomatie comme Expérience de l'Autre: Consuls Français au Maghreb (1700-1840) (Geneva: Droz, 2002), 282-90. 
In this context, it has to be said that it also makes little sense to imagine, for the period before the nineteenth century, a Europe that has already advanced from 'feudalism' to a type of pre-bourgeois period in contrast to a sub-Saharan Africa still dominated by 'feudal' structures. Marxist scholars have made this claim for the African context - where, interestingly enough, it connects to the logic of Modernisation Theory, the 'capitalist' theory with its apogee in the 1960 s and still influential afterwards, which explains different levels of economic development in distinct world regions with velocities in the evolution of socio-political structures. However, any attempts at classifying sub-Saharan African power structures as 'feudal' are entirely artificial. ${ }^{136}$ Within African political entities, control of land and control of the means of production are rather unimportant compared to the factor of access to manpower, as expressed in the concept of 'wealth-through-people': it is difficult to imagine larger African communities as 'feudal.'.137 On the contrary, early West African states have been discussed as successful in regard to the two basic tasks of organising essential 'services', notably in a savannah region where access to food and stability of trade routes were the central goals, or in a coastal tropical forest zone, where slave-raiding and a higher population density made smaller units with appropriate protective power more attractive. Perhaps the greatest obstacle to any process of bureaucratisation in the African continent was the absence of reliable and widely available script systems to be employed for administrative processes; even with some local languages expressed in a written form with Arabic characters, we do not know, for West Africa, any broader process of appropriation of written languages for the purposes of control and raising of tribute, for example. 138

Following the strict definition according to Reinhard, many of these entities could not be considered as 'states'. With several rulers of West African political units attempting, in the course of the eighteenth century, to improve the efficiency of their structures - perhaps in relation to the expansion of slave traderelated contacts - the situation slowly changed. While such efforts may seem minimal in contrast to European developments in the eighteenth and nineteenth century, they sharpened nonetheless the discrepancies in West African regions between more strongly centralised political entities and their neighbours organised at village level. Building on a tradition that involved the use of

${ }_{13} 6$ Jensen, Rolf, 'The Transition from Primitive Communism: The Wolof Social Formation of West Africa', Journal of Economic History 42(1), 1982, 69-76.

137 See Levtzion, Nehemia, Ancient Ghana and Mali (New York: Africana, 1980).

138 Herbst, Jeffrey, States and Power in Africa: Comparative Lessons in Authority and Control (Princeton: Princeton University Press, 2000), 41-6. 
professionalised army units, some rulers elaborated, above all, a more sophisticated structure of military organisation. This was backed up, however, by the employment of a more formalised and increasingly effective system of taxraising, tributes, and internal administration. ${ }^{139}$

The pre-colonial entities of Asante and Dahomey, being forerunners in the eighteenth century, are classical examples for such processes of 'state-building' in West Africa. Asante appears as most strongly developed in those respects: in the Asante capital, Kumase, we even find attempts at formalising rules through the employment of Arabophone scribes by the territorial administration. As written language was discovered as a particularly efficient means for the codification of rules, these attempts illustrate a broader change within the mentalities of regional representatives of power.

However, regarding the nature of local repertoires of identification in West Africa, these refined methods and trends towards bureaucratisation as employed by Asante's officials were probably not a necessary factor for an attachment of locals to the power structures they lived in. Even with somewhat looser institutions, the regular appearance of representatives of administrative power amongst them, either for tribute-raising or for protection, clearly shaped the perceptions of local populations. Moreover, in the more densely populated coastal zones, where a large number of smaller political units (again called 'states' in the less strict English terminology) existed, the representatives of political power were active in sometimes quite engaged attempts at local diplomacy and alliance-building. Such diplomatic efforts, whose outcomes were frequently known to the subjects, contributed to the creation of an in-group perception that referred to the 'state': the success of diplomacy was regarded as success for the whole community. ${ }^{140}$

It appears that state-related solidarities could in some cases produce even stronger effects on the individual. For Akyem Abuakwa in present-day Ghana, for which we have one of the most detailed analyses of such sentiments in the population, Richard Rathbone has argued for the emergence of a feeling of 'citizenship'. This akyemfo sentiment, to refer to the expression in the Twi language, is clearly separated from ethnic and 'national' notions. It allowed local

\footnotetext{
139 In English terminology, it thus seems appropriate to distinguish between 'specialised states', 'segmentary states', and 'stratified communities', see Southall, Aidan W., 'State Formation in Africa', Annual Review of Anthropology 3, 1974, 153-65, 155-7.

140 Boahen, A.A., 'Fante diplomacy in the eighteenth century', in Kenneth Ingham (ed.), Foreign Relations of African States (London: Butterworths, 1974), 25-49; Irwin, Graham W., 'Precolonial African Diplomacy: the Example of Asante', International Journal of African Historical Studies 8(1), 1975, 81-96.
} 
populations to identify themselves as belonging to a given political structure. In a process that was both from the top down and from the bottom up, the inhabitants of Akyem Abuakwa relied on and felt obliged to the pre-colonial 'state'.141 In this context, it has rightly been pointed out that it would be improper and overzealous to assume that in similar cases state identification naturally overlaps with a particular ethnic identification. As Archie Mafeje has made clear for Bunyoro and other interlacustrine kingdoms in Central Africa, many African states were indeed multi-ethnic projects. ${ }^{142}$

It would be interesting to follow the evolution of such sentiments of state loyalty during the colonial and post-colonial phases. We find little research carried out concerning this particular question. ${ }^{143}$ In most studies, the state as an independent variable is superseded with regard to the motivations of local populations by ethnicity or 'the nation'. For the pre-colonial situation, it is frequently claimed that African populations were mainly organised by kinship groups and networks, which would have blended into a loose-knit framework of larger political entities. From such a perspective, one could then argue, for the colonial period, that the institutions created by the colonisers were regarded as a reality that was so foreign and distant in comparison to the former local realities that these new institutions did not allow for any identification. ${ }^{144}$ However, we need to review that opinion in light of the above-mentioned experience of slow centralisation of some political units in West Africa before the end of the nineteenth century.

Moreover, it is a well-known and remarkable fact that African elites were in time won over to cultural values introduced from the colonial metropoles, and that a considerable number of those Africans actively 'assimilated' to European cultural standards, as French colonial officials called it. ${ }^{145}$ While the colonial

141 Rathbone, Richard, 'Defining Akyemfo: The Construction of Citizenship in Akyem Abuakwa, Ghana, 1700-1939', Africa 66(4), 1996, 506-25.

142 Mafeje, Archie, The Theory and Ethnography of African Social Formations: The Case of the Interlacustrine Kingdoms (London: CODESRIA, 1991), 47.

143 An exception (but with a limited empirical fundament) is Englebert, Pierre, 'Pre-Colonial Institutions, Post-Colonial States, and Economic Development in Tropical Africa', Political Research Quarterly 53(1), 2000, 7-36.

144 Ekeh, Peter, 'Individuals' Basic Security Needs \& the Limits of Democracy in Africa', in Bruce Berman, Dickson Eyoh, and Will Kymlicka (eds.), Ethnicity and Democracy in Africa (Oxford: James Currey - Athens/on: Ohio University Press, 2004), 22-37, 28; Herbst, States, 90-3.

145 Sabatier, Peggy, 'Did Africans Really Learn to Be French? The Francophone Elite of the Ecole William Ponty', in G. Wesley Johnson (ed.), Double Impact: France and Africa in the Age of Imperialism (Westport - London: Greenwood Press, 1985), 179-87. 
state was in many cases nearly invisible in the more peripheral regions of the colonies, it is nevertheless a crucial task to analyse how it was regarded by inhabitants of the regions where the European presence could be felt more directly. The processes of identification with colonial rule and the particular forms of administration created by the Europeans still await such analysis. The meagre data that has so far been presented concerning the question of African attitudes towards the colonial state as substitute for the pre-colonial political entities does not even allow us, for the moment, to speculate upon these attitudes.

Finally, for the post-colonial situation, we also lack in-depth studies pointing to such identifications of individuals with the state structures they lived in. It has been argued - as I pointed out - that the post-colonial African state is an expression of the 'politics of the belly', but it is unclear whether individuals that constantly had to interact with the organisms of the state, however inefficient, might feel they belong to the respective entity. ${ }^{146}$ Nonetheless, there has been a consensus that the leaders of dominant African parties, and indeed of other political movements as well, were eager to create their own symbols of affiliation: in many cases their leadership included its own variant of identity politics, with the formulation of founding myths as an alternative to ethnic solidarity and to 'harden' the national structures. ${ }^{147}$ Finally, the gap between the state level and its agents on the one hand, and the (marginalised) local populations on the other hand, might have led to the creation of a certain type of 'civil society' - but we still do not know how these forms relate to either the existing state structures or to ethnic sentiment. ${ }^{148}$ With those different variables of identification presented, it remains now for me to discuss how they relate to each other in the empirical cases and in a broader, global, history, and to interpret under which model conditions we can imagine them to interact. $^{149}$

146 Bayart, Etat, 309-13.

147 Hayward, Fred M., and Ahmed R. Dumbuya, 'Political Legitimacy, Political Symbols, and National Leadership in West Africa', Journal of Modern African Studies 21(4), 1983, 645-71, 652-3, 658-9; Forrest, Joshua, 'The Quest for State 'Hardness' in Africa', Comparative Politics 20(4), 1988, 423-42, 435-7.

148 Lemarchand, René, 'Uncivil States and Civil Societies: How Illusion Became Reality', Journalof Modern African Studies 3o(2), 1992,177-91,186-7; Owusu, Maxwell, 'Domesticating Democracy: Culture, Civil Society, and Constitutionalism in Africa,' Comparative Studies in Society and History 39(1), 1997, 120-52, 129-30; Nyang'oro, Julius E., 'Reform Politics and the Democratization Process in Africa', African Studies Review 37(1), 1994, 133-49, 147.

149 Hopkins, A.G., 'The New Economic History of Africa', Journal of African History 5o(2), 2009, 155-77, 171-3. 


\section{The Complexities of Choice}

According to 'constructivist' theories, ethnic affiliation is a question of decisions made consciously or in reaction to decision processes carried out at a certain level of the individual's community. Village communities, clans, or migrating groups are all possible entities within which to locate this level of decision. ${ }^{150}$ Normally, scholars seek decision-making processes at a very high level: the main protagonists are believed to be regional politicians, party leaders, and sometimes the heads of rebellious groups. Still more typical, according to the analysis frequently presented in contemporary 'constructivist' scholarship, the architects of ethnic sentiment are very often foreign to the local communities: they might be representatives of the colonial power, or, in another very prominent setting, the members of a new political elite that, with decolonisation, became powerful through ethnic manipulation. As I remarked, the latest 'constructivist' historiography does not necessarily continue with this radical position and is more differentiated, but the principal idea of external manipulation continues to be an essential element of the debate.

There remains, however, the question from which basis the mobilisation through identifications starts, or where exactly the manipulators begin with their work. ${ }^{151}$ A model that seeks to explain ethnic solidarity convincingly probably needs to approach the fact that in at least apparently similar situations, groups are mobilised through notions of ethnic sentiment, of religion, of social status, of regional interest, or others, the latter including the categories of 'race', 'nation' and 'state solidarity' that I have discussed in detail. John Thompson, while focusing excessively on the interplay of 'ethnicity' and 'class' to the detriment of other alternatives, has rightly pointed to the fact that all complex societies are characterised by what he calls 'structural ambiguities'.152 Such alternative choices have likewise been discussed for the importance of the categories of 'ethnicity' and 'race' in relation to 'religion'.153

\footnotetext{
150 Owusu, Maxwell, 'Democracy and Africa - A View from the Village', Journal of Modern African Studies 3o(3), 1992, 369-96, 383-4; Geschiere, Peter, 'Applications of the Lineage Mode of Production in African Studies', Canadian Journal of African Studies 19(1), 1985, 8o-9o, 92-3.

$15^{1}$ Ake, Claude, 'Charismatic Legitimation and Political Integration', Comparative Studies in Society and History 9(1), 1966, 1-13, 10-1.

${ }^{152}$ Thompson, John L.P., 'The plural society approach to class and ethnic mobilization', Ethnic and Racial Studies 6(2), 1983, 127-53, 131-2.

153 Stanczak, Gregory, 'Strategic ethnicity: The construction of multi-racial/multi-ethnic religious community', Ethnic and Racial Studies 29(5), 2006, 856-81, 870-2.
} 
This leaves us with the question of agency, which, in the African case, is so often sought in the activities of either colonial officials or African opinionmakers. We find a recent counter-attempt to lay the emphasis on the potential of decision-making as held by local populations. This explanatory attempt alleges that individuals are able to 'calculate' the usefulness of ethnic solidarity, and activate this variable when it is advantageous or promising for larger goals. This idea had already been elaborated, under the keyword of 'situational ethnicity', in scholarly approaches of the early 1980 s. ${ }^{154}$ However, only in most recent times has this perspective been at the forefront of studies.

In a recent monograph, Daniel N. Posner measures the potential of 'situational ethnicity' for understanding the ethnic factor in sub-Saharan Africa during post-colonial elections. He creates a model according to which individuals are perfectly able to play the ethnic card whenever they really believe this choice to be useful. Posner holds that the individuals concerned can select from a repertoire or portfolio of affiliations, which include ethnicity, but which also comprise other variables such as 'race', religion, or region of origin. As far as this is rationally possible, voters of African countries seem to calculate (or estimate) the respective strength of different available group configurations, and then select the appropriate element on which to rely for electoral success. In some cases and for some individuals, ethnic affiliation is likely to be the right choice. ${ }^{155}$

Nonetheless, even as part of an identifications repertoire, the local voters can define the category of 'ethnicity' in quite different ways. Focusing on the case of elections in post-colonial Zambia, Posner characterises 'language' and 'tribe' as the two main variants available for a definition of ethnic group solidarity, at least in this particular South Central African country. However, the author comments that other identifications can also be addressed as parts of (and, thus, integrated into) the concept of ethnic identification, such as, in particular, religion and regional sentiment. Thus, in Posner's view, the category of ethnic solidarity has a great flexibility; it depends on an ad hoc consensus of the community to decide about the basic criteria for describing the ethnic in-group. ${ }^{156}$

154 Okamura, Jonathan Y., 'Situational ethnicity', Ethnic and Racial Studies 4(4), 1981, 452-65, 454-5.

155 Decalo, Samuel, 'The Process, Prospects and Constraints of Democratization in Africa', African Affairs 91(362), 1992, 7-35, 9-10, 13.

156 Posner, Institutions; see also: Salomone, Frank A., 'Becoming Hausa: ethnic identity change and its implications for the study of ethnic pluralism and stratification', Africa 45(4), 1975, 410-25, 422; Schultz, Emily A., 'From Pagan to Pullo: Ethnic Identity Change in Northern Cameroon', Africa 54(1), 1984, 46-64, 50-1. 
Posner's point of view is highly stimulating insofar as he offers a usable interpretation of the aspect of choice in group identifications. Moreover, he also explains the limits of such choice. His individuals and groups have their instrumentalist perspective of ethnic affiliation: they decide their affiliation by an (attempted) perspective of finding the best strategy to secure power and material assets through electoral success. ${ }^{157}$ Nonetheless, the more essential point of Posner's analysis is his claim that individuals live with a certain portfolio of ways of identification, with which they ultimately have to work in order to succeed. The same portfolio, however, does not offer an infinite range of alternatives of identification for a given situation: possibilities of choice are sensibly limited by the elements that are present inside it. Other social scientists have possibly already expressed the idea of an identifications repertoire, but Posner's perseverance has been crucial to point out the importance of the idea. ${ }^{158}$

While Posner's perspective is inspiring, its basic conclusions are, of course, impossible to simply transfer from the restricted field of electoral behaviour in a particular southern African country to the more general patterns of ethnic alliance-building and ethnic conflict in sub-Saharan Africa and in global history over the last decades and centuries. It is correct that, in recent decades, strong links have been found between the ethnic self-description of group members, and their voting behaviour. ${ }^{159}$ In the post-independence years, leading African politicians held that parliamentary democracy had to be eliminated on the grounds that elections were likely to wake 'tribal' dissension. This idea seems to be partly confirmed by recent scholarly studies. ${ }^{160}$

157 Mozaffar, Shaheen; James R. Scarritt, and Glen Galaich, 'Electoral Institutions, Ethnopolitical Cleavages, and Party Systems in Africa's Emerging Democracies', American Political Science Review 97(3), 2003, 379-90, 388.

158 Posner, Daniel N., 'Measuring Ethnic Fractionalization in Africa', American Journal of Political Science 48(4), 2004, 849-63, 852-4.

159 Gray, Robert F., 'Political Parties in New African Nations: An Anthropological View', Comparative Studies in Society and History 5(4), 1963, 449-61, passim.

16o Mousseau, Demet Yalcin, 'Democratizing with Ethnic Divisions: A Source of Conflict?', Journal of Peace Research 38(5), 2001, 547-67, 551-2; Smith, Zeric Kay, "The Impact of Political Liberalisation and Democratisation on Ethnic Conflict in Africa: An Empirical Test of Common Assumptions', Journal of Modern African Studies 38(1), 2000, 21-39, 34; Udogu, E. Ike, 'The Issue of Ethnicity and Democratization in Africa: Toward the Millennium', Journal of Black Studies 29(6), 1999, 790-808, 804-6; Jackson, Robert H., and Carl G. Rosberg, 'Popular Legitimacy in African Multi-Ethnic States', Journal of Modern African Studies 22(2), 1984, 177-98, 188-91. 
Voting is a process with established rules, to which all participating parties commit themselves at least for the given moment, and the final act of voting is introduced by a long and normally relatively safe preparatory phase. ${ }^{161}$ During this phase, individuals have a range of opportunities to study the given situation, including from some distance, and reflect upon electoral strategies. In other situations in which conflicting parties do not have a regulatory framework it is obviously far more difficult to see behind choices of allegiance an elaborated strategic behaviour. ${ }^{162}$ Nevertheless, there have also been attempts to look at ethnically motivated civil wars through the prism of rational choice. ${ }^{163}$ Information is again an important factor in this context. In rural settings and in areas of underdeveloped infrastructure in particular, it is plausible that individuals positioning themselves as group members had only scant information about the more general panorama and suffered from a lack of means of communication. ${ }^{164}$

Nonetheless, while it is obviously impossible to transpose Posner's model on to situations of group conflict in general, his approach gives important impetus. In particular, his idea of identification repertoires is quite fertile. ${ }^{165}$ In my own analysis, I will gladly draw on a part of Posner's approach. In the case studies, I will focus on ethnic affiliation as part of a portfolio, together with other factors, which might under particular circumstances rival its role. Those factors must be regarded as viable alternatives in some phases of the existence of groups, and more so under conditions of colonial rule.

The approach of more or less rational (sometimes also emotional) choice gains credibility by the fact that many of the local identifications are far from being contradictory to ethnic sentiment. In some cases, they even seem to interact with one another; and, according to Thomas Hylland Eriksen, a 'semioverrule' of conflicting identities between two groups can be observed in cases in which group members or group leaders, or both, declare another category of

161 Horowitz, Donald L., Ethnic Groups in Conflict (Berkeley - London: University of California Press, 1985), 261-440; Londregan, John; Henry Bienen, and Nicolas van den Walle, 'Ethnicity and Leadership Succession in Africa', International Studies Quarterly 39, 1-25, 21.

162 Muller, Edward N., and Erich Weede, 'Cross-National Variation in Political Violence: A Rational Action Approach', Journal of Conflict Resolution 34(4), 1990, 624-51, 628-9.

163 Azam, 'Looting', 137-41, 146-8.

164 Smith, Susan J., 'Negotiating ethnicity in an uncertain environment', Ethnic and Racial Studies 7(3), 1984, 360-73, 365-7.

165 On additional approaches on the 'autonomy of the individual', see Douglas, Mary, 'How Identity Problems Disappear', in Anita Jacobson-Widding (ed.), Identity: Personal and Socio-cultural (Uppsala - Stockholm: Almqvist \& Wiksell International - Atlantic Highlands: Humanities Press, 1983), 35-46. 
identification as more appropriate for the solution of a particular problem. ${ }^{166}$ Thus we find indications that individuals, in the process of group-building, have a tendency to draw on various alternatives, to evaluate them according to their immediate needs, while respecting as well existing alliances based on these allegiances, which make it difficult to simply change the latter. ${ }^{167}$ Moreover, larger groups appear to be favoured over smaller units when it comes to processes of ethnic mobilisation. This result points to the strategic context of ethnic visions. ${ }^{168}$

In a recent article, Rogers F. Brubaker and Frederick Cooper have argued that insistence on the flexibility of categories of identification questions the concept of 'identity' in itself. They have also warned against the use of categories that play a role for individual or group identifications, as these categories have to be accounted for by demonstrating at which particular moments they gain importance. ${ }^{169}$ While the first point is of course justified, it must nevertheless be said that there are myriads of ethnic, religious, social, and other allegiances that are effectively barred to an individual or to a group of individuals. Therefore, if the researcher keeps in mind that the repertoire has its (frequently rather strict) limits, the concept of different and overlapping categories of identification retains its importance. Brubaker's and Cooper's second point corresponds to what I intend to do in this book.

The West African case studies will thus attempt to address the different aspects of discussing group identifications. They will analyse the evolution of ethnic identifications according to the recent, consensual approach that regards ethnicity as a complex mixture of pre-colonial (although not necessarily 'primordial') and later 'constructed' affinities. Their examination will set ethnic solidarity in the matrix of repertoires, in which it has to position itself in relation to aspects of identification such as 'the nation' and 'race', not omitting regional and smaller, village solidarities. It will also bring the state into this panorama as another, strongly neglected, problem for both the pre-colonial political entities and the colonial state. Finally, I will question the plausibility of rational behaviour as an explanation for position changes regarding the individuals' group identities, and bring the results into a global historical perspective.

166 Eriksen, Thomas Hylland, 'Complexity in social and cultural integration: Some analytical dimensions', Ethnic and Racial Studies 30(6), 2007, 1055-69, 1062.

167 Green, Elliot G., 'Understanding the Limits to Ethnic Change: Lessons from Uganda's “Lost Counties"', Perspectives on Politics 6(3), 2008, 473-85, 480-1.

168 Cohen, David William, and E.S. Atieno Odhiambo, 'Ayany, Malo and Ogot: Historians in Search of a Luo Nation', Cahiers d'Etudes Africaines 27(107), 1987, 269-86, 277-9.

169 Brubaker, Rogers, and Frederick Cooper, 'Beyond “Identity", Theory and Society 29(1), 2000, $1-47,6,11-2$. 